\title{
Artur Zimny
}

Uniwersytet Łódzki

e-mail: artur.zimny@uni.lodz.pl

\section{EFEKTYWNOŚĆ INWESTYCJI \\ W AKCJE NOTOWANYCH W POLSCE SPÓLEK PRIVATE EQUITY}

\section{THE EFFICIENCY OF INVESTMENTS \\ IN SHARES OF PRIVATE EQUITY COMPANIES LISTED IN POLAND}

DOI: 10.15611/nof.2017.1.08

JEL Classification: G11

Streszczenie: W artykule przedstawiono analizę efektywności inwestycji w akcje spółek, które prowadzą działalność na rynku private equity, notowanych na polskim publicznym rynku akcji (zidentyfikowano 29 takich spółek). Wykazano, że inwestycje w te akcje przynoszą generalnie wyższe stopy zwrotu niż z indeksu WIG (przyjętego za benchmark), ale też cechują się znacznie wyższym ryzykiem inwestycyjnym (mierzonym odchyleniem standardowym). Efektywności tych inwestycji (mierzonej wskaźnikami Sharpe'a i Treynora) nie można uznać za wyższą od efektywności inwestycji w benchmark (WIG), co jednak nie znaczy, że jest ona niższa. Ponadto stwierdzono słabą korelację stóp zwrotu $\mathrm{z}$ akcji notowanych spółek private equity ze stopami zwrotu z WIG, z czego wynika, iż akcje te są instrumentami pozwalającymi znacznie redukować ryzyko portfeli inwestycyjnych.

Słowa kluczowe: private equity, efektywność inwestycji w akcje, optymalizacja portfela inwestycyjnego.

Summary: The paper presents the analisys of the eficiency of investing in shares of companies operating on private equity market and quoted on Polish public equity market (29 such companies was identified). It has been shown that investments in these shares generally bring higher rates of return than WIG (chosen as benchmark), but with significantly higher risk accompanied (measured by standard deviation). The efficiency of such investments (measured by Sharpe and Treynor ratios) cannot be considered higher than the efficiency of investment in the benchmark (WIG), which does not mean that it is lower. The study also showed that the correlation between rates of return from the shares of listed private equity companies and the rates of return from WIG is low, which implies that these shares are instruments enabling significant reduction of risk of investment portfolios.

Keywords: private equity, efficiency of investemts in shares, investment portfolio optimisation. 


\section{Wstęp}

Private equity na stałe wpisało się w krajobraz systemów finansowych niemal całego świata. Ten specyficzny typ finansowania, zapoczątkowany w połowie XX wieku równolegle w USA i w Europie (głównie Wielkiej Brytanii), umożliwił rozwój wielu dynamicznych, innowacyjnych przedsiębiorstw, nierzadko towarzysząc im od stadium „firmy garażowej” do statusu potentata w swojej branży. Jednocześnie częstokroć finansowane projekty kończyły się bankructwami, co jednak jest typowe w biznesie - wyższa dochodowość nierozerwalnie wiąże się z ponoszeniem wyższego ryzyka.

Rynek private equity jest segmentem rynku kapitałowego odrębnym i zgoła odmiennym od rynku publicznego (giełd papierów wartościowych ${ }^{1}$ ), istnieje jednak między nimi kilka istotnych powiązań. Jedno z nich polega na tym, że podmioty prowadzące działalność private equity mogą pozyskiwać kapitały przez emisję papierów wartościowych na rynku publicznym. Papiery te, wprowadzone do notowań, są potencjalnym elementem strategii inwestycyjnych inwestorów giełdowych.

Problemem badawczym podjętym w niniejszym artykule jest efektywność inwestycji w akcje notowanych w Polsce spółek private equity; postawiono pytanie, na ile efektywność ta różni się od efektywności charakteryzującej cały rynek akcji (specyfika działalności private equity sugeruje, że może ona być istotnie różna). Celem pracy jest zbadanie tej efektywności i rozstrzygnięcie tak postawionego problemu badawczego. Rozwiązanie problemu uzyskano w drodze zbadania efektywności przedmiotowych inwestycji za pomocą instrumentów znanych $\mathrm{z}$ analizy portfelowej (średnich stóp zwrotu, ryzyka mierzonego odchyleniem standardowym stóp zwrotu, wskaźników efektywności Sharpe’a i Treynora oraz korelacji stóp zwrotu).

\section{Rynek private equity i jego powiązania z publicznym rynkiem akcji}

W niniejszym artykule termin private equity (w skrócie: PE) używany jest zgodnie z rozumieniem rozpowszechnionym zarówno wśród badaczy, jak i dostarczycieli danych dotyczących tego finansowania, które można zdefiniować jako „kapitał inwestowany w udziały przedsiębiorstw nienotowanych na rynku papierów wartościowych $\mathrm{w}$ celu osiągnięcia zysku kapitałowego przez przyrost wartości tych przedsiębiorstw i odsprzedaż udziałów po upływie z góry przewidzianego okresu". Definicja ta implikuje zasadnicze cechy odróżniające ten typ finansowania od dwóch głównych jego alternatyw - giełdy i długu. Private equity polega na inwestowaniu

${ }^{1}$ „Publiczny rynek akcji” jest, co do zasady, pojęciem szerszym niż „giełda”, obejmuje bowiem także alternatywne systemy obrotu publicznego, jednakże to rozróżnienie pojęciowe zaciera się i dlatego w niniejszej pracy wymienione terminy używane są jako synonimy; rynek NewConnect również traktowany jest tu jak rynek giełdowy. 
w spółki nienotowane na giełdzie (z pewnymi wyjątkami), ale jest finansowaniem zasadniczo udziałowym, w przeciwieństwie do kredytu czy obligacji. Ponadto podmioty dokonujące tych inwestycji zwykle aktywnie wspomagają swoje spółki portfelowe w prowadzeniu ich działalności, by zwiększyć szanse na wspólny sukces - inaczej, niż to jest w przypadku inwestorów giełdowych (z reguły pasywnych) oraz dawców kapitału dłużnego.

$\mathrm{Z}$ terminem private equity ściśle wiąże się pojęcie venture capital, które zwykle rozumiane jest jako podzbiór private equity, obejmujący inwestycje w przedsięwzięcia będące na wczesnych etapach rozwoju. Poza zawężoną polityką inwestycyjną finansowanie venture capital $\mathrm{w}$ zasadzie nie różni się od private equity, dlatego w niniejszej pracy rozróżnienie to nie jest istotne.

Choć, jak wspomniano, private equity i giełdy papierów wartościowych to odrębne rynki, mogą jednak występować między nimi pewne istotne powiązania. Przedstawiono je na rys. 1.

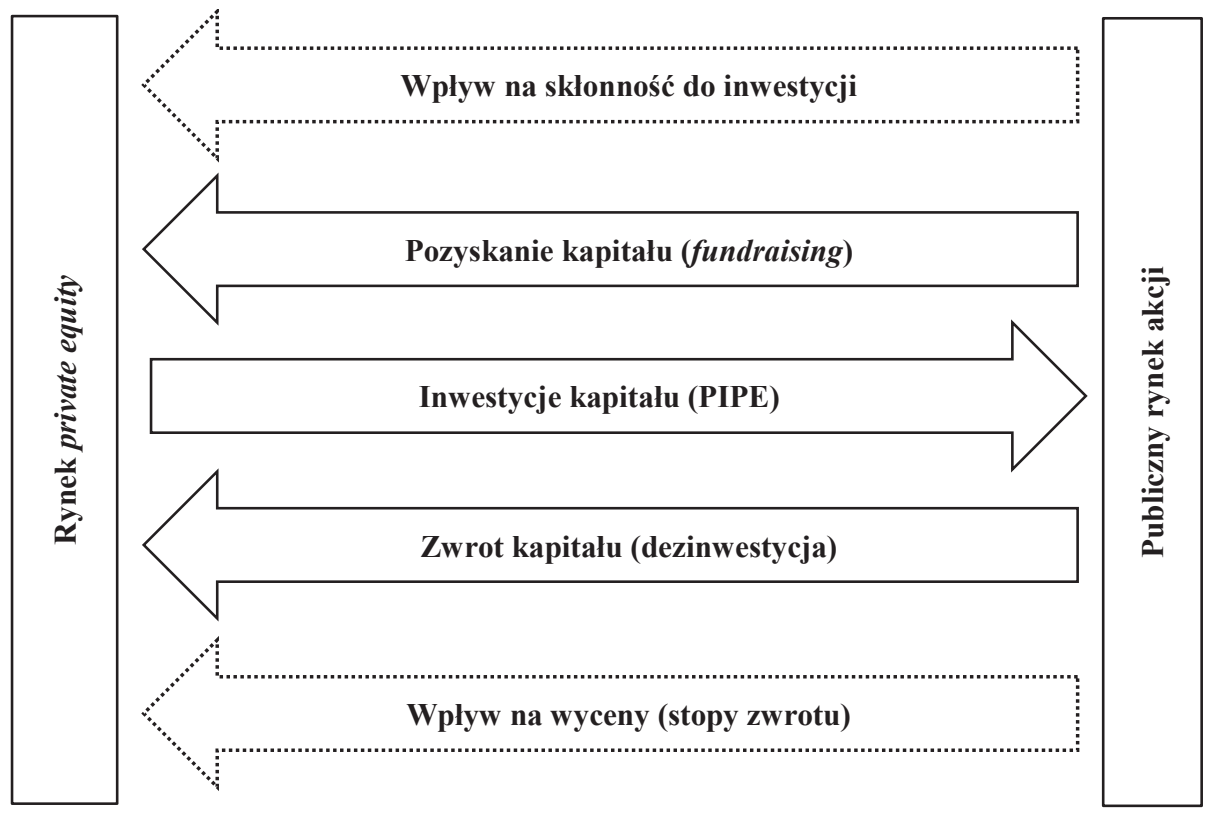

Rys. 1. Możliwe powiązania rynku private equity z publicznym rynkiem akcji

Źródło: opracowanie własne.

Pierwszą z relacji przedstawionych na rys. 1, niepolegającą na bezpośrednim przepływie środków, jest wpływ koniunktury panującej na giełdach na skłonność kapitałodawców do angażowania swoich środków w fundusze private equity. Ponadto podmioty prowadzące działalność PE mogą pozyskiwać kapitał bezpośrednio poprzez giełdę, choć źródła statystyczne podają, że jest to relatywnie mały odsetek 
pozyskiwanych środków [Invest Europe 2016]. Przepływem kapitału w przeciwnym kierunku mogą być inwestycje firm PE w spółki notowane na giełdzie (określane jako PIPE - Private Investment in Public Equity), które nie mieszczą się w klasycznej definicji terminu private equity, polegającego - jak zaznaczono - na inwestycjach w przedsiębiorstwa nienotowane. Inwestycje PIPE są niejako wyjątkami potwierdzającymi regułę, zdarzają się one bowiem rzadko i stanowią zwykle mało istotny udział w strukturze portfeli inwestycyjnych PE. Ostatnim elementem cyklu inwestycyjnego private equity jest dezinwestycja (sprzedaż udziałów w spółce portfelowej w celu realizacji zysków); nabywcami mogą być inwestorzy giełdowi, co oznacza kolejne powiązanie dwóch omawianych rynków (i kolejny przepływ kapitałów między nimi). Koniunktura giełdowa może też mieć istotny wpływ na transakcje dezinwestycji, a konkretnie na skłonność firm PE do wybierania giełdy jako drogi upłynnienia udziałów oraz na wartości wycen oferowanych spółek portfelowych (także jeśli proponuje się ich sprzedaż inwestorom innym niż giełdowi).

Powiązania te bywają przedmiotem analiz, także w literaturze krajowej - badaniu poddano np. wpływ koniunktury giełdowej na skłonność inwestorów do angażowania środków w fundusze PE oraz na skłonność firm PE do preferowania giełdy jako formy dezinwestycji [Zimny 2009; 2013a], efektywność tych dezinwestycji przez polską giełdę papierów wartościowych [Sosnowski 2014; Zasępa 2010] oraz wpływ koniunktury giełdowej na stopy zwrotu osiągane z inwestycji PE [Zimny 2013a; 2013b]. Pozostałe relacje wydają się mało eksplorowane przez polskich badaczy, w przeciwieństwie do naukowców z zagranicy, co jednak wynika zapewne $\mathrm{z}$ wciąż relatywnie krótkiego okresu istnienia rynku PE w Polsce w porównaniu z jego „starymi” i wysoko rozwiniętymi odpowiednikami w innych krajach.

W niniejszym artykule skupiono się na obecności firm PE na polskim publicznym rynku akcji (GPW, NewConnect), przy czym przyjęto punkt widzenia inwestorów giełdowych, którzy mogliby być zainteresowani akcjami tych firm. Przedmiotem zainteresowania jest więc efektywność inwestycji w akcje takich spółek oraz ich atrakcyjność z perspektywy dywersyfikacji ryzyka portfela inwestycyjnego.

\section{Specyfika inwestowania w notowane spółki private equity}

Dość często spotkać można przekonanie, iż inwestycje typu private equity charakteryzują się wysoką dochodowością (przekonanie to wzmagają zapewne szeroko raportowane przykłady spektakularnych sukcesów firm, odniesionych przy współudziale takiego finansowania). Niezależnie od tego, jakie rzeczywiście stopy zwrotu osiąga się w tej branży, należy pamiętać, że prawo do profitów z działalności funduszu private equity ma - oprócz zespołu zarządzającego tym funduszem - tylko wąskie grono inwestorów, którzy zaangażowali weń swe środki. Fundusze PE są zwykle funduszami zamkniętymi, co oznacza, że kapitałodawcy angażują w nie swoje środki z nastawieniem, iż wycofają je dopiero po zakończeniu całego cyklu inwestycyjnego, tj. po upłynnieniu udziałów w spółkach portfelowych. Ta specyfika powo- 
duje, że oferta funduszy PE zwykle skierowana jest do ograniczonej grupy inwestorów, którzy dysponują odpowiednio dużymi zasobami pieniędzy. Innymi słowy, drobni inwestorzy (jakich wielu uczestniczy w obrocie giełdowym) do rynku PE nie mają dostępu. Wyjątkiem są sytuacje, w których papiery wartościowe podmiotu PE (firmy zarządzającej lub funduszu) zostają wprowadzone do publicznych notowań. Takie walory umożliwiają szerokiemu gronu inwestorów uczestnictwo w rynku PE oraz dywersyfikowanie swoich portfeli przez dodawanie do nich kolejnej, nietypowej klasy aktywów inwestycyjnych. Inwestor musi jednak mieć świadomość, że wzbogacając swój koszyk inwestycyjny o potencjalnie wysoko dochodowy instrument, wprowadza do niego również dodatkowe ryzyko, które ze względu na charakter działalności spółek PE jest też nietypowe. To powoduje, że atrakcyjność takiej inwestycji nie jest wcale oczywista. Odpowiedź na pytanie, na ile atrakcyjne są inwestycje w takie walory, to główny cel niniejszego artykułu.

Inwestowanie $\mathrm{w}$ notowane spółki PE $\mathrm{w}$ porównaniu $\mathrm{z}$ inwestycjami $\mathrm{w}$ typowe (nienotowane) podmioty tego typu ma wiele zalet, są to zwłaszcza:

- brak konieczności oczekiwania na zaproszenie ze strony podmiotu gromadzącego środki (typową formą pozyskiwania środków na inwestycje PE jest organizowanie funduszy, do których zapraszani są odpowiednio zasobni inwestorzy);

- niski koszt dostępu do danych potrzebnych do oceny inwestycji (spółki notowane mają dość szerokie obowiązki sprawozdawcze, podczas gdy firmy nienotowane są zwykle bardzo oszczędne w tym zakresie; dostępne są badania [Cumming $\mathrm{i}$ in. 2011] wykazujące, że właśnie z tego powodu notowane PE są bardziej atrakcyjną klasą aktywów dla mniejszych inwestorów instytucjonalnych);

- niskie minimum kapitału, jaki trzeba zainwestować (dzięki istnieniu rynku wtórnego wyznacza je w zasadzie cena najtańszej akcji spółki PE dostępnej na giełdzie; przy organizacji typowego, nienotowanego funduszu PE oferta jest skierowana do wąskiego grona inwestorów, od których wymaga się znacznych porcji kapitału);

- dostęp do ciągłej wyceny inwestycji (w przypadku udziału w nienotowanym funduszu PE informacje o stanie aktywów są inwestorom dostarczane okresowo);

- wysoka płynność (dzięki istnieniu rynku wtórnego, dostępnego wielu inwestorom; w przypadku udziału w funduszu nienotowanym zbycie udziałów w celu przedterminowego wycofania się z inwestycji jest bardzo utrudnione).

Z kolei wadą takiego inwestowania może być dodatkowe ryzyko wynikające z wahań koniunktury giełdowej: oprócz ryzyka strat z tytułu nietrafionych inwestycji firmy PE (typowego także dla nienotowanych firm PE) kurs akcji notowanej spółki PE może spadać bardziej, niż to wynika z ich wewnętrznej wartości, z powodu ogólnych nastrojów spadkowych na giełdzie. Ryzyko to jednak powinno być niskie, jeśli korelacja między wynikami notowanych PE a wynikami całego rynku jest niska (co stanowi jeden $\mathrm{z}$ elementów badania $\mathrm{w}$ niniejszej pracy).

Inwestowanie w notowane PE ma też pewne zalety w porównaniu z inwestowaniem w notowane spółki z innych branż, zwłaszcza niefinansowych (przemysł, usłu- 
gi itp.). Po pierwsze, jest to dodatkowa (wtórna) dywersyfikacja inwestycji; przy inwestowaniu $\mathrm{w}$ nowe emisje spółek z sektorów niefinansowych pozyskane przez nie środki są zwykle inwestowane w konkretne aktywa (środki trwałe, technologie itd.), natomiast notowane firmy PE lokują te środki w spółki portfelowe, a dopiero one inwestują je $\mathrm{w}$ dalsze aktywa. Po drugie natomiast, inwestycje w notowane PE (które docelowo trafiają do spółek portfelowych z różnych branż) są mało podatne na szczególne zdarzenia dotykające konkretne branże (np. wszystkie notowane banki ucierpią z powodu wprowadzenia podatku bankowego, notowane spółki handlowe - z powodu podatku od sieci handlowych, notowane spółki paliwowe są narażone na skoki światowych cen ropy, notowania spółek energetycznych zależą od regulacji rynku energii itd.).

Wprowadzanie firm PE do notowań publicznych zyskuje na popularności, czego przejawem jest oferowanie inwestorom narzędzi (indeksów, funduszy inwestycyjnych) grupujących notowane spółki PE; jako przykłady można podać:

- Listed Private Equity Index (LPX) [LPX Group], grupa indeksów obejmujących notowania spółek PE; najbardziej znany indeks LPX 50 obejmuje 50 największych notowanych spółek PE na świecie;

- PowerShares Global Listed Private Equity Portfolio [Invesco PowerShares 2016], oparty na indeksie Red Rocks Global Listed Private Equity Index, który obejmuje od 40 do 75 instrumentów notowanych spółek PE z różnych regionów świata (głównie z USA i Wielkiej Brytanii);

- S\&P Listed Private Equity Index [McGraw Hill Financial 2016], który obejmuje wiodące notowane spółki PE (głównie z USA, Wielkiej Brytanii i Kanady).

Wyrazem dążenia do samoorganizacji notowanych firm PE jest powstanie stowarzyszenia Listed Private Equity (LPEQ), które - w przeciwieństwie do innych, bardziej znanych stowarzyszeń tego typu (jak Invest Europe, NVCA, BVCA itd.) zrzesza tylko notowane firmy PE. Stowarzyszenie to opublikowało poradnik [LPEQ 2014] dotyczący inwestowania w notowane spółki PE.

\section{Efektywność inwestycji w notowane $P E$ w świetle dotychczasowych badań}

Efektywność inwestycji w notowane PE nie jest częstym przedmiotem badań, stanowi bowiem dość wąski obszar badawczy, na dodatek leżący na styku dwóch dziedzin traktowanych zwykle odrębnie - efektywności inwestycji giełdowych i rynku private equity. Istnieją jednak publikacje dotyczące tej tematyki. Dla niniejszej pracy istotne są nie tylko te, w których analizowana jest sama efektywność inwestycji w notowane PE, ale także te, w których badano, na ile wyniki notowanych PE mogą reprezentować działalność nienotowanych firm z tej branży, dla których o wiele trudniej o stosowne dane. Taki problem podjął m.in. M. Huss [2005], który przedstawił badania wyników inwestycyjnych notowanych i nienotowanych firm PE. Oprócz wykorzystania typowego narzędzia używanego do takich analiz ( $\mathrm{tj}$. IRR - wewnętrz- 
nej stopy zwrotu), które uznał on za obarczone pewnymi wadami, zastosował również specjalnie dobraną metodę kalkulacji (PME - Public Market Equivalent), która jest tych wad pozbawiona. Rezultatem badań było stwierdzenie, iż wyniki notowanych i nienotowanych firm PE różnią się od siebie nieistotnie mało, co oznacza, że można przyjąć, iż wyniki inwestycji w notowane spółki PE (w badaniu reprezentowane przez będący benchmarkiem indeks LPX 50) są dobrym reprezentantem wyników inwestycji w nienotowane fundusze PE. Potwierdzenie tego wniosku można znaleźć w pracy M. Degosciu [2012], który porównywał wyniki notowanych i nienotowanych PE, bazując na danych o stopach zwrotu opartych na wartościach netto aktywów tych funduszy (tzw. NAV - Net Asset Value). Analizy wykazały m.in. silną korelację pomiędzy stopami zwrotu z indeksu LPX50 NAV Index a stopami zwrotu nienotowanych funduszy PE, jak również to, że wyrażone wartościami NAV wyniki funduszy nienotowanych mogą być $\mathrm{w}$ znacznym stopniu wyjaśniane (w formie funkcji regresji) wynikami indeksu LPX50 NAV Index, podczas gdy znaczenie szerokiego rynku akcji (mierzonego indeksem MSCI World) jako zmiennej objaśniającej miało niewielkie znaczenie. Wymienione prace podnoszą wartość badań nad notowanymi PE, wykazują bowiem, że wyniki takich badań mogą być (oczywiście przy odpowiednich zastrzeżeniach) uogólniane na cały sektor PE.

Badania efektywności inwestycji w notowane PE znacznie ułatwiło pojawienie się wspomnianych indeksów grupujących notowania wiodących spółek PE. B. Bergmann, H. Christophers, M. Huss i H. Zimmermann [2010], oprócz analizy form organizacyjno-prawnych preferowanych przez notowane i nienotowane firmy PE oraz zalet inwestowania $\mathrm{w}$ instrumenty firm notowanych, przedstawili również wyniki analizy stóp zwrotu i ryzyka indeksu LPX50 w odniesieniu do dwóch wybranych benchmarków (indeksów MSCI World i Nasdaq Composite) w latach 1994-2008. Autorzy podzielili ten okres na 4 podokresy, cechujące się naprzemiennie czynnikami napędzającymi i hamującymi koniunkturę inwestycyjną (boom internetowy, pęknięcie bańki internetowej, boom na rynku buyouts oraz kryzys po krachu na rynku kredytów subprime). Analiza wykazała, że indeks notowanych PE (LPX50) dawał bardzo zróżnicowane stopy zwrotu w porównaniu z benchmarkami; w pierwszych dwóch podokresach był pomiędzy nimi, w trzecim dał stopę zwrotu wyższą od nich, a w czwartym - niższą. Ryzyko, mierzone odchyleniem standardowym, w pierwszych trzech podokresach było wyższe od ryzyka indeksu MSCI i niższe od Nasdaq, w ostatnim podokresie zaś okazało się najwyższe, znacznie odbiegając od pozostałych dwóch. Na podstawie tych danych nie można więc przyjąć, że indeks notowanych PE daje wyraźnie lepsze lub wyraźnie gorsze wyniki niż benchmarki, do których jest porównywany. Cenna byłaby tu jeszcze analiza dochodowości w relacji do ryzyka (dobrze ilustrowana np. wskaźnikiem Sharpe'a), której jednak autorzy nie przedstawili. Ale podane w pracy średnie stopy zwrotu podzielone przez wartości ryzyka także nie pozwalają stwierdzić jednoznacznej przewagi efektywności inwestycji w indeks LPX50 nad pozostałymi dwoma indeksami (jest ona wyraźna jedynie w trzecim z badanych podokresów). Należy zaznaczyć, że autorzy wskazują na 
znaczny wpływ, jaki na wyniki indeksu LPX50 wywierają strategie inwestycyjne spółek, których instrumenty wchodzą w skład tego indeksu: firmy venture capital osiągały bardzo dobre wyniki w okresie boomu internetowego, zwiększając stopę zwrotu $\mathrm{z}$ indeksu $\mathrm{w}$ pierwszym badanym podokresie (i obniżając $\mathrm{w}$ drugim, gdy na giełdach pękła bańka), a z kolei wysokie stopy zwrotu w trzecim podokresie były w znacznym stopniu efektem boomu na rynku wykupów (buyouts).

Autorzy zbadali również korelacje między wybranymi klasami aktywów globalnego rynku kapitałowego (reprezentowanymi przez wybrane indeksy) i stwierdzili, że najsilniejsza korelacja występuje między inwestycjami typu private equity a inwestycjami w akcje (wskaźnik wyniósł 0,772). Silnie skorelowana z private equity (wskaźnik 0,659), jak i z rynkiem akcji (wskaźnik 0,686) okazała się również klasa aktywów określona jako infrastruktura (infrastructure). Każda $\mathrm{z}$ tych trzech klas jest z kolei umiarkowanie (wskaźnik od 0,423 do 0,517) skorelowana z klasą określoną jako nieruchomości (real estate). Ostatnia $\mathrm{z}$ analizowanych klas, tj. obligacje (bonds), okazała się najsłabiej skorelowana z każdą z pozostałych klas (wskaźnik od 0,002 dla korelacji z private equity do 0,371 dla korelacji z akcjami).

S. Bilo, H. Christophers, M. Degosciu i H. Zimmermann [2005] zbadali wyniki inwestycji w notowane PE, bazując na licznej próbie (ponad 100) notowanych instrumentów. Badaniu poddano przeliczone na roczne (annualized) tygodniowe stopy zwrotu w latach 1986-2003 (z podziałem na dwa podokresy), obliczone dla trzech portfeli złożonych z tych instrumentów (każdy z portfeli konstruowany był w oparciu o inaczej sformułowane założenia dotyczące udziałów poszczególnych instrumentów). W badaniu dokonano i szczegółowo opisano kilka istotnych korekt na zestawie analizowanych danych w celu wyeliminowania (na ile to możliwe) tzw. błędów systematycznych (bias), prezentując wpływ tych korekt na wyniki badanych portfeli. Badanie wykazało, że efektywność inwestycji w notowane PE (mierzona wskaźnikiem Sharpe'a) wszystkich trzech portfeli znacznie przewyższała efektywność inwestycji w szeroki rynek akcji (reprezentowany przez indeks MSCI World) w okresie boomu giełdowego (1986-2000), ale w okresie po pęknięciu bańki internetowej (czyli po roku 2000) tylko jeden z tych portfeli dał efektywność wyższą niż z ogólnego rynku akcji. Oznacza to, że przewaga efektywności inwestycji w notowane PE nad inwestycjami w akcje ogółem nie jest oczywista, a co więcej, że w znacznym stopniu zależy ona od przyjętego stylu inwestycyjnego, który wyraża się założeniami co do struktury udziałów poszczególnych instrumentów w portfelu notowanych PE.

Z kolei M. Sharma i R. Aggarwal [2012] analizowali zachowanie indeksu S\&P Listed Private Equity Index w odniesieniu do wybranych benchmarków (indeksów S\&P 400, S\&P 500, S\&P 600, S\&P 1200) w latach 2007-2011, wykorzystując roczne i miesięczne stopy zwrotu, ryzyko (mierzone odchyleniem standardowym) oraz wskaźniki Sharpe'a. Badanie wykazało, że efektywność inwestycji w indeks spółek PE była generalnie niższa niż dla benchmarków. Ponadto autorzy dokonali analizy regresji, na podstawie której stwierdzili, że zmienność tego indeksu może być 
w bardzo wysokim stopniu (96\% dopasowania) objaśniana kombinacją indeksów S\&P 400, S\&P 600, S\&P 1200 jako zmiennych objaśniających, co oznacza silną korelację między indeksem spółek PE a ogólną koniunkturą na rynku akcji. Analogiczne badania wykonali K. Small, D. Duncan i E. Small [2013], przy czym ich zakres był szerszy - analizie poddano dwa indeksy notowanych spółek PE (PowerShares Global Listed Private Equity Portfolio oraz S\&P Listed Private Equity Index), zestawiając ich wyniki z szerszą grupą benchmarków (S\&P 500, S\&P 1000, S\&P 1000 Value, S\&P 1000 Growth, S\&P 400 Mid-Cap, S\&P 600 Small-Cap, MSCI Canada, MSCI Sweden, MSCI UK, MSCI France oraz MSCI Belgium). Analiza również obejmowała dane za lata 2007-2011. Co do samych średnich stóp zwrotu, oba indeksy notowanych spółek PE wykazały zdecydowanie gorsze wyniki niż prawie wszystkie benchmarki. Przy analizie stóp zwrotu w relacji do ryzyka (wyrażonych wskaźnikiem Sharpe'a) różnica nie była już tak znaczna: indeksy notowanych spółek PE dały wyniki generalnie słabsze niż inne indeksy z rodziny S\&P, ale nieodbiegające od wyników notowanych przez indeksy MSCI analizowanych w pracy. Autorzy wykonali również badanie regresji, w którym zmienną objaśniającą były stopy zwrotu z indeksu PowerShares Global Listed Private Equity Portfolio, i stwierdzili dość wysoki związek tego indeksu z zachowaniem szerokiego rynku akcji w USA (np. dla indeksu S\&P 1000 jako zmiennej objaśniającej uzyskano 79,45\% dopasowania), natomiast włączenie indeksów MSCI do funkcji regresji przyniosło bardzo niewielką poprawę stopnia objaśnienia zmiennej objaśnianej.

Nieco odmienne podejście do tematu zaprezentowali P. Aigner, G. Beyschlag, T. Friederich, M. Kalepky i R. Zagst [2012], którzy badali nie tyle efektywność inwestycji w notowane PE, ile uwzględnienie takich instrumentów (reprezentowanych przez indeks LPX 50) w szerszym portfelu inwestycyjnym. Autorzy ci wykazali, że przy optymalizacji portfela inwestycyjnego złożonego z akcji i obligacji włączenie do niego akcji notowanych firm private equity zwiększa jego efektywność dzięki silnemu efektowi dywersyfikacji, nawet dla inwestora o wysokiej awersji do ryzyka.

Przytoczone wyniki badań umożliwiają uogólnienie następujących wniosków:

1) nie można przyjąć, że efektywność inwestycji w notowane PE jest wyższa lub niższa niż efektywność inwestycji w akcje w ogóle; występują okresy naprzemiennie wyższej i niższej efektywności;

2) związek wyników inwestycji w notowane PE z wynikami inwestycji w akcje ogółem jest niejednoznaczny; niektóre badania wykazały wysoki stopień korelacji, inne z kolei sugerują, że jest on niski, skoro ich wprowadzenie do portfeli daje silny efekt dywersyfikacji i redukcję ryzyka.

Powyższe badania dotyczyły spółek PE z różnych państw, a wykorzystywano w nich głównie indeksy, czyli agregaty grupujące wiele spółek PE. W niniejszej pracy natomiast postanowiono skupić się na rynku polskim, dla którego brak analogicznego indeksu, dlatego analizie poddana została cała grupa notowanych firm PE. 


\section{Hipotezy badawcze}

Podstawową przesłanką do sformułowania zagadnień badawczych było pytanie, na ile rzekoma wysoka dochodowość i ryzykowność inwestycji private equity jako takich przekłada się na dochodowość i ryzykowność inwestycji w akcje notowanych firm PE. Obiegowe opinie dotyczące wysokiej dochodowości z inwestycji PE sugerują, że parametry te powinny być wyższe niż przeciętne dla całego rynku akcji. Z kolei wyższa dochodowość i jednocześnie wyższe ryzyko rodzi naturalne pytanie, czy relacja tych dwóch parametrów (rozumiana jako efektywność inwestycyjna) jest lepsza niż przeciętna dla całego rynku akcji. Dzieje się tak, gdy dostępna dla danej klasy aktywów premia za ryzyko w stosunku do samego ryzyka jest odpowiednio wyższa niż średnia dla całego rynku. Niezależnie od tego, czy inwestycje w notowane PE są efektywne, wartym rozważenia zagadnieniem jest włączanie tych instrumentów do szerzej zdefiniowanych portfeli inwestycyjnych - pojawia się tu pytanie, czy jest to strategia uzasadniona. Celem takiej dywersyfikacji jest zwykle podnoszenie dochodowości całego portfela przy relatywnie niedużym zwiększaniu (a najlepiej obniżaniu) łącznego ryzyka. Efekt taki osiąga się zwykle, gdy instrumenty włączane do portfela charakteryzują się wysoką dochodowością i jednocześnie niską korelacją stóp zwrotu z pozostałymi instrumentami z portfela.

$\mathrm{Z}$ uwzględnieniem powyższych przesłanek sformułowano następujące hipotezy badawcze:

Hipoteza 1: Stopy zwrotu z inwestycji w akcje spółek private equity notowanych na polskim rynku akcji są wyższe niż stopy zwrotu z całego rynku akcji.

Hipoteza 2: Ryzyko inwestycji w akcje spółek private equity notowanych na polskim rynku akcji jest wyższe niż ryzyko dla całego rynku akcji.

Hipoteza 3: Efektywność inwestycji w akcje spółek private equity notowanych na polskim rynku akcji jest wyższa niż efektywność dla całego rynku akcji.

Hipoteza 4: Akcje notowanych w Polsce spółek private equity pozwalają znacznie redukować ryzyko portfeli inwestycyjnych złożonych z akcji dostępnych na polskim rynku.

\section{Spólki private equity notowane na polskim rynku akcji}

Dla zbadania efektywności inwestycji w akcje spółek private equity notowanych na polskim rynku konieczne było ich wyodrębnienie z całego zbioru spółek notowanych publicznie. O ile spółki z niektórych branż łatwo wyodrębnić dzięki dedykowanym indeksom giełdowym (np. WIG-banki, WIG-energia, WIG-media itd.), o tyle nie ma takiego indeksu dla grupy spółek prowadzących działalność private equity ani też indeksu grupującego spółki z szerzej rozumianej dziedziny finansów (wyjątkiem jest wspomniany indeks grupujący banki). Popularne wśród inwestorów portale internetowe stosują pewne grupowania branżowe, przy czym zdarzają się rozbieżności między takim przyporządkowaniem danej spółki a jej faktycznym profilem 
działalności. Dlatego identyfikację, czy dana spółka prowadzi działalność private equity, oparto głównie na opisach podawanych na stronach internetowych spółek. W ten sposób przeanalizowano dokładniej ok. 170 spółek, wychwytując te, dla których inwestycje typu private equity (w tym venture capital) są działalnością główną lub przynajmniej jedną z głównych. Analizą objęto zarówno spółki notowane na regulowanym rynku giełdowym, jak i w alternatywnym systemie obrotu (NewConnect). W ten sposób wyłoniono 29 spółek. Należy zaznaczyć, że przeglądu dokonano obecnie, bez badania historii notowań, czyli nie zostały uwzględnione spółki, które były dawniej notowane, prowadziły działalność private equity i jej zaprzestały lub zostały wycofane z notowań. Wydaje się jednak, że takie przypadki były nieliczne.

Należy również zauważyć, że oprócz akcji spółek PE dostępne są jeszcze inne instrumenty inwestycyjne umożliwiające ekspozycję na rynek private equity. Najważniejszym są certyfikaty inwestycyjne funduszy o takiej specjalizacji; fundusze takie, organizowane przez firmy PE, mogą być zasilane kapitałami pozyskiwanymi poprzez publiczny rynek kapitałowy. Są one zwykle organizowane w formie funduszy zamkniętych (stąd certyfikaty, a nie jednostki uczestnictwa). Oprócz tego znane są przypadki emisji obligacji przez firmy PE (w takim przypadku ryzyko inwestora jest znacznie ograniczone, ale - co za tym idzie - niższa jest także potencjalna dochodowość). Firma MCI, jedna z najstarszych notowanych w Polsce spółek PE, przeprowadzała emisje obu rodzajów wymienionych papierów wartościowych (tj. certyfikatów i obligacji). Nie można też wykluczyć istnienia innych instrumentów, mogących służyć do przepływu kapitału na rynek private equity poprzez publiczny rynek kapitałowy. Badanie wszystkich takich możliwości byłoby zbyt rozległe, dlatego w niniejszej pracy ograniczono się jedynie do akcji notowanych spółek PE.

Listę spółek PE notowanych na GPW i NewConnect, wraz z ich charakterystyką, przedstawiono $\mathrm{w}$ tab. 1.

Przełom lat 2000 i 2001 na rynkach światowych, a zwłaszcza na rynku akcji w USA, to okres szczególny, doszło bowiem wówczas do kulminacji bańki internetowej, która wywindowała notowania na giełdach do niespotykanych poziomów, by po pęknięciu przynieść wielu inwestorom potężne straty. Wahania polskich indeksów giełdowych nie były wówczas tak znaczne, ale wyraźna była zmiana liczby debiutów, która spadła z ok. 60 rocznie (lata 1997 i 1998) do mniej niż 10 (lata 2001-2003) [GPW]. Jak wskazują dane zebrane w tab. 1, spośród obecnie notowanych spółek PE tylko trzy były w obrocie przed rokiem 2000, z tego dwie to niegdysiejsze Narodowe Fundusze Inwestycyjne. Po roku 2000 debiutowały tylko pojedyncze spółki, większa fala takich debiutów nadeszła dopiero w latach 2007-2008 (6 spółek, które trafily do tab. 1); okres ten znowu okazał się przełomowy, tym razem przez krach na rynku kredytów typu subprime, który „rozlał się” na cały rynek finansowy. Kolejne nasilenie debiutów, jak wynika z tab. 1, zaczęło się w roku 2010 i potrwało do 2013; wszystkie spółki debiutujące w tym okresie notowane są na NewConnect. Najmłodsza stażem w publicznym obrocie spółka PE jest notowana przez niewiele ponad rok. 
Tabela 1. Spółki private equity notowane w Polsce i ich charakterystyki

\begin{tabular}{|c|c|c|c|c|c|c|}
\hline Nazwa & $\begin{array}{c}\text { Data } \\
\text { rozpoczęcia } \\
\text { notowań* }\end{array}$ & Rynek & Ticker & Kapitalizacja** & $\begin{array}{c}\text { Wartość } \\
\text { księgowa** }\end{array}$ & $\begin{array}{l}\text { Wskaźnik } \\
\text { C/WK** }\end{array}$ \\
\hline Magna Polonia SA & 1997.06 & GPW & $06 \mathrm{~N}$ & 27,84 & 50,27 & 0,55 \\
\hline Impera Capital SA & 1997.06 & GPW & IMP & 14,57 & 26,98 & 0,54 \\
\hline Calatrava Capital SA & 1997.11 & GPW & CTC & 14,25 & 1,06 & 13,44 \\
\hline MCI Capital SA & 2001.02 & GPW & $\mathrm{MCI}$ & 639,42 & 1212,50 & 0,53 \\
\hline Capital Partners SA & 2002.09 & GPW & CPA & 64,17 & 107,82 & 0,60 \\
\hline bmp Holding AG & 2004.12 & GPW & BMP & 63,35 & 71,95 & 0,88 \\
\hline Blumerang Investors SA & 2007.12 & $\mathrm{NC}$ & BLU & 6,24 & 12,66 & 0,49 \\
\hline IQ Partners SA & 2007.12 & GPW & IQP & 11,62 & 28,60 & 0,41 \\
\hline Invista SA & 2008.01 & GPW & INV & 28,92 & 44,90 & 0,64 \\
\hline Erne Ventures SA & 2008.02 & $\mathrm{NC}$ & ERN & 51,04 & 23,88 & 2,14 \\
\hline Investment Friends Capital SA & 2008.02 & GPW & IFC & 10,21 & 23,05 & 0,44 \\
\hline Skyline Investment SA & 2008.03 & GPW & SKL & 5,40 & 26,18 & 0,21 \\
\hline Black Pearl SA & 2010.03 & $\mathrm{NC}$ & $\mathrm{BPC}$ & 32,36 & 12,61 & 2,57 \\
\hline Leonidas Capital SA & 2010.06 & $\mathrm{NC}$ & LEO & 19,50 & 1,19 & 16,40 \\
\hline Venture Incubator SA & 2010.06 & $\mathrm{NC}$ & VTI & 51,94 & 8,60 & 6,04 \\
\hline Quark Ventures SA & 2010.11 & $\mathrm{NC}$ & QRK & 8,99 & 31,84 & 0,28 \\
\hline Runicom SA & 2011.01 & $\mathrm{NC}$ & RUN & 1,26 & $-1,65$ & $-0,76$ \\
\hline Taxus Fund SA & 2011.01 & $\mathrm{NC}$ & TXF & 149,46 & 227,18 & 0,66 \\
\hline Silesia One SA & 2011.02 & $\mathrm{NC}$ & SSO & 1,41 & 1,14 & 1,24 \\
\hline Grempco SA & 2011.03 & $\mathrm{NC}$ & GRM & 3,45 & 36,89 & 0,09 \\
\hline Aerfinance SE & 2011.05 & $\mathrm{NC}$ & AER & 3,01 & 10,68 & 0,28 \\
\hline Venture Capital Poland SA & 2011.07 & $\mathrm{NC}$ & VCP & 1,22 & $-0,01$ & $-122,00$ \\
\hline Novina SA & 2012.06 & $\mathrm{NC}$ & $\mathrm{NOV}$ & 2,77 & 42,85 & 0,06 \\
\hline Centurion Finance SA & 2012.08 & $\mathrm{NC}$ & CTF & 19,16 & 7,94 & 2,41 \\
\hline Merit Invest SA & 2012.08 & $\mathrm{NC}$ & MEI & 1,01 & 0,15 & 6,68 \\
\hline Setanta SA & 2013.01 & $\mathrm{NC}$ & SET & 84,01 & 20,11 & 4,18 \\
\hline $\mathrm{PCH}$ Venture SA & 2013.03 & $\mathrm{NC}$ & PCV & 1,56 & 1,49 & 1,04 \\
\hline Grupa Trinity SA & 2013.04 & $\mathrm{NC}$ & GTY & 10,81 & 41,64 & 0,26 \\
\hline Private Equity Managers SA & 2015.04 & GPW & PEM & 367,03 & 100,57 & 3,65 \\
\hline
\end{tabular}

* Datę rozpoczęcia notowań podano według [Stooq]; w niektórych przypadkach różni się ona od daty podawanej przez [GPWInfoStrefa]. ** Dane o kapitalizacji (wartość akcji w obrocie, w mln zł), wartościach księgowych netto (w mln zł) i wartościach wskaźnika C/WK pochodzą z [Stooq].

Źródło: opracowanie własne na podstawie [GPWInfoStrefa; NewConnect; Stooq; Bankier; Money.pl] oraz stron internetowych poszczególnych spółek.

Liczba zidentyfikowanych notowanych spółek PE okazała się nieco zaskakująca. Monitoringiem polskiego rynku PE zajmuje się Polskie Stowarzyszenie Inwestorów Kapitałowych (PSIK), które zrzesza działające w Polsce podmioty prowadzące inwestycje tego typu. Lista tych podmiotów, podana na stronie Stowarzyszenia [PSIK], zawiera 51 firm zarządzających funduszami PE, z czego tylko 5 (Impera Capital, MCI Capital, Capital Partners, IQ Partners i Skyline Investment) to firmy 
notowane, ujęte w tab. 1. Oznacza to, że przeważająca większość notowanych firm PE nie należy do PSIK, i jednocześnie sugeruje, że na polskim rynku może funkcjonować wiele nienotowanych firm PE, również nienależących do PSIK, a co za tym idzie, że łączna liczba działających w Polsce firm PE znacznie przekracza tę podaną na stronie Stowarzyszenia (a tym bardziej tę podawaną przez stowarzyszenie Invest Europe, według którego w 2015 r. firm PE mających siedzibę w Polsce było 40 [Invest Europe]).

Tabela 1 zawiera również dane o kapitalizacji i wartości księgowej notowanych spółek PE. Charakterystyczny jest bardzo duży rozrzut tych wartości. Jeśli chodzi o wartość księgową, różnica między MCI a pozostałymi firmami jest ogromna, choć firmy zajmujące w tym rankingu pozycję trzecią (Capital Partners) i czwartą (Private Equity Managers) również dzieli od drugiej (Taxus Fund) znaczny dystans. Wyraźnie odbiegająca od pozostałych jest jeszcze firma bmp Holding, pozostałe dają się pogrupować w dość wyraźne kategorie: 12 firm o wartości od 20 do $50 \mathrm{mln}$ zł, 5 firm o wartości od 8 do $13 \mathrm{mln}$ zł i 7 firm o wartości poniżej 1,5 mln zł (z czego dwie o stratach przekraczających dodatnie pozycje kapitałów własnych). Oceniając te dane, należy mieć na uwadze, że niekoniecznie odzwierciedlają one kapitał pozostający pod zarządem tych firm, bo ten może być wielokrotnie wyższy (firmy mogą obracać kapitałem zebranym $\mathrm{w}$ ramach własnej konstrukcji organizacyjno-prawnej lub w postaci odrębnego funduszu, niewykazywanego jako własne aktywa). Ranking wartości rynkowych (kapitalizacji) wyraźnie się różni od wycen księgowych, czego wynikiem jest znaczny rozrzut wartości wskaźnika C/WK (cena do wartości księgowej). Większość spółek charakteryzuje wskaźnik o wartości mniejszej niż 1, co interpretuje się jako niedowartościowanie waloru (cenę rynkową niższą od przypadającej nań wartości księgowej netto) i potencjalnie atrakcyjną okazję inwestycyjną. Wskaźnik wyższy od 1 oznacza przewartościowanie, co może oznaczać przypisywanie spółce przez inwestorów dużego potencjału wzrostowego, ale zwykle trudno ocenić, czy nie jest to nadmiar optymizmu; ponadto wskaźnik może też wzrosnąć gwałtownie w wyniku opublikowania danych o poniesionych stratach, co zdecydowanie jest sytuacją niekorzystną. Największe przewartościowanie wykazują dwie z najmniejszych spółek: Calatrava Capital oraz Leonidas Capital. Oczywiście w najgorszej sytuacji są spółki o wskaźniku ujemnym, tj. Venture Capital Poland i Runicom.

Charakteryzując dane finansowe wyszukanych spółek, nie można pominąć specyfiki ich notowań. Relatywnie dużą część z nich charakteryzują niskie ceny jednostkowe akcji (tzw. akcje groszowe) oraz niska płynność, przejawiająca się bardzo małym wolumenem obrotu; zdarzało się, że na niektórych akcjach nie występowała żadna transakcja przez kilka miesięcy. Choć zazwyczaj zaleca się pomijanie takich instrumentów w badaniach, w tym wypadku podjęto decyzję o ich niewyłączaniu, za czym przemawiały dwa argumenty. Po pierwsze, rzadkie transakcje powodują, że na danym walorze osiąga się bardzo niską uśrednioną stopę zwrotu (ponieważ do średniej wchodzi wiele zerowych wyników) przy relatywnie wyższym odchyleniu stan- 
dardowym, co powinno dawać niską wartość wskaźnika Sharpe'a, a zatem wskaźnik ten powinien adekwatnie odzwierciedlać niską efektywność inwestycji w takie akcje. Po drugie, usunięcie tych z założenia „gorszych” spółek z całego zbioru poddawanego analizie mogłoby sztucznie poprawić wyniki całego zbioru i doprowadzić do wniosków niesłusznie zniekształconych na korzyść firm PE.

Zjawiskiem charakterystycznym dla notowanych firm PE jest znaczący spadek kursu po debiucie (w większości przypadków od razu po debiucie, w niektórych - po krótkotrwałym okresie wzrostów). Co istotne, schemat ten powtórzył się prawie we wszystkich badanych przypadkach, a więc nie tylko w tych, w których spadki mogły być wywołane ogólną dekoniunkturą na giełdzie (równocześnie znaczne spadki indeksu WIG), ale też w tych, w których indeksy giełdowe rosły. Pojawia się tu naturalne pytanie, czy firmy te nie były wprowadzane do notowań według mocno zawyżonych wycen, skoro rynek tak konsekwentnie i znacząco je korygował. Oczywiście schemat ten ma też przełożenie na wskaźniki efektywności, przy czym nie jest z góry przesądzone, że powinny się one charakteryzować niską oceną, ta bowiem zależy także od stóp zwrotu uzyskiwanych w toku dalszych notowań, już po okresie pierwotnych spadków.

Notowane spółki PE mają też specyficzne zasady redystrybucji osiągniętych zysków. W wypadku notowanych spółek PE często przekłada się to na szczególną politykę dywidendową, która polega na ich niewypłacaniu [LPEQ, s. 4]. Podobnie jest w odniesieniu do firm PE notowanych w Polsce - przy poszukiwaniu danych do badania udało się dotrzeć do informacji o zaledwie 10 wypłatach dywidend przeprowadzonych przez 4 spośród 29 spółek wymienionych w tab. 1. Należy stąd wnioskować, że bazą kreowania dochodu przy inwestycjach w te akcje jest przede wszystkim sam przyrost ich wartości.

\section{Metodyka badania}

Zbadanie hipotez wymagało wyznaczenia dla wszystkich notowanych spółek PE oraz dla benchmarku:

- stóp zwrotu za poszczególne interwały czasowe,

- średnich stóp zwrotu dla wybranych okresów,

- odchyleń standardowych stóp zwrotu (reprezentujących ryzyko) dla tych okresów,

- korelacji stóp zwrotu spółek PE ze stopami zwrotu z benchmarku (WIG),

- wartości współczynnika determinacji dla funkcji regresji między stopami zwrotu ze spółek PE a stopami zwrotu z benchmarku (WIG),

- wartości współczynników beta,

- wskaźników Sharpe'a,

- wskaźników Treynora.

Metodyka przeprowadzania powyższych obliczeń i interpretacji wyników jest dobrze opisana, także w rodzimej literaturze [Jajuga, Jajuga 2001; Tarczyński 1997]. 
Za podstawowy benchmark odzwierciedlający stopy zwrotu i efektywność inwestycji w szeroki rynek akcji przyjęto indeks WIG. Pomocniczo w analizie oceniano też indeks NCI, reprezentujący rynek NewConnect. Ponieważ jednak to WIG jest uważany za główny barometr koniunktury na polskim rynku akcji (NCI ma o wiele krótszy staż i małą kapitalizację), korelacje i regresje stóp zwrotu oraz współczynniki beta spółek notowanych na NC wyznaczono także w odniesieniu do indeksu WIG.

Notowania spółek PE i indeksów giełdowych pobrano z serwisu stooq.pl; udostępniane tam dane mają tę zaletę, że uwzględniają przeliczone wstecz splity i scalenia akcji, dzięki czemu zdarzenia te nie zniekształcają stóp zwrotu za okresy, w których wystąpiły. W przypadku braku obrotu na danej akcji przez kolejne okresy przyjęto w nich ostatni znany kurs zamknięcia (uzyskując za te okresy zerowe stopy zwrotu). Przy obliczaniu stóp zwrotu w liczniku (zysk netto) uwzględniono oprócz zmiany kursu akcji także dywidendy (netto) wypłacone w danych okresach, nie uwzględniono natomiast wystąpienia w poszczególnych przypadkach praw poboru (indeksy WIG i NCI, jako dochodowe, uwzględniają oba te elementy), przy czym przyjęto, że ewentualny wpływ tych zdarzeń na długookresowe charakterystyki dochodowości i ryzyka notowanych spółek PE jest znikomy i nieistotny statystycznie.

Do analizy stóp zwrotu i ryzyka inwestycji w akcje, zwłaszcza tak specyficzne, jak spółek PE, powinno się wykorzystywać stopy zwrotu za długie interwały, np. roczne, ale historia tych spółek jest za krótka, by można było uzyskać w ten sposób odpowiednio liczne szeregi czasowe, dlatego zdecydowano się na interwały miesięczne. Badany okres podzielono na 4 krótsze okresy, by z jednej strony wykorzystać dane za starsze lata, dotyczące tych nielicznych spółek, które są notowane najdłużej, a z drugiej strony nie pominąć tych, które staż na publicznym rynku akcji mają stosunkowo krótki. Okresy te w zamierzeniu miały być równe, ale podczas badania natrafiono na problem, który wymusił korektę ich długości. Problemem tym jest kwestia interpretacji wskaźników Sharpe'a w okresach, dla których wskaźnik ten jest ujemny dla benchmarku. W typowej sytuacji (wskaźniki dodatnie) wskaźnik Sharpe'a dla danego waloru wyższy od wskaźnika Sharpe'a dla benchmarku oznacza wyższą efektywność inwestycyjną. Gdy jednak oba wskaźniki są ujemne, ta prosta zasada przestaje być oczywista. Zaprezentowano to na rys. 2, na którym punkt M oznacza portfel rynkowy, a punkty A i B - dwa portfele porównywane z rynkowym (punkt $\mathrm{F}$ to instrumenty wolne od ryzyka). Gdyby kierować się współczynnikiem Sharpe'a, należałoby stwierdzić, że portfel B jest lepszy od rynkowego, a portfel A gorszy. Tymczasem jest dokładnie na odwrót: to portfel A przy tej samej średniej stracie ma mniejsze ryzyko niż portfel rynkowy, portfel B zaś - większe, dlatego za efektywniejszy należy uznać portfel A (charakteryzujący się niższym wskaźnikiem Sharpe'a).

Z opisanym powyżej problemem można postąpić trojako: 1) zastosować wolną od tej wady modyfikację wskaźnika Sharpe'a lub wskaźnik alternatywny, 2) w opisie rozgraniczać interpretację dla okresów, w których benchmark ma wskaźnik dodatni i ujemny, 3) tak dobrać okresy analizy, by wskaźnik Sharpe'a dla benchmarku był 


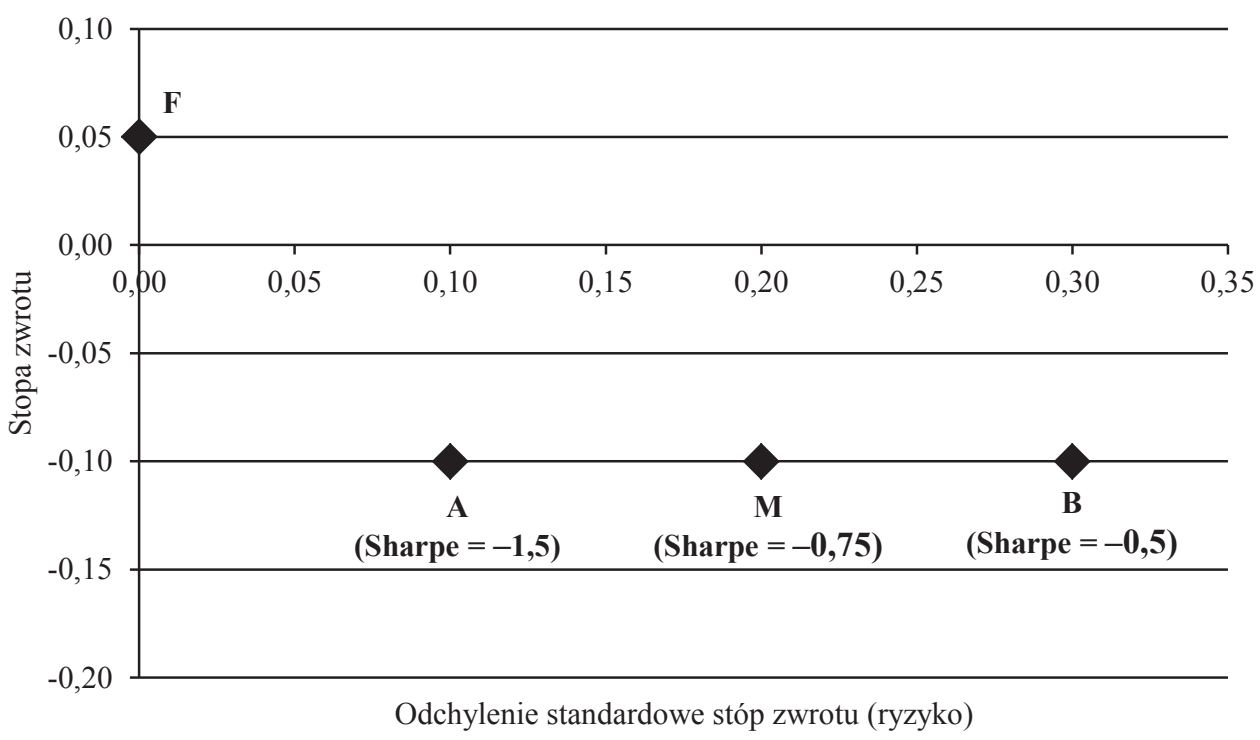

Rys. 2. Nieintuicyjność interpretacji ujemnych wskaźników Sharpe’a

Źródło: opracowanie własne.

dodatni. Dwa pierwsze sposoby uznano za zbyt kłopotliwe i mało czytelne w ostatecznych wnioskach, dlatego zadecydowano o wyborze sposobu trzeciego. Aby uzyskać dodatnią premię za ryzyko, licząc od sierpnia 2016 r. wstecz, trzeba było do analizy przyjąć okres dłuższy niż 3 lata, dlatego zdecydowano się na okresy 4-letnie, uzyskując 4 takie okresy (łącznie 16 lat). Ponieważ jednak trzeci z tych okresów dawał nadal ujemną premię za ryzyko (i w rezultacie ujemny wskaźnik Sharpe'a), skrócono go o 1 miesiąc, wydłużając okres poprzedni.

W ten sposób uzyskano następujące okresy analizy:

1) okres 1, od 2000.09 do 2004.08, 48 miesięcy, 3 notowane spółki PE;

2) okres 2, od 2004.09 do 2008.09, 49 miesięcy, 5 notowanych spółek PE;

3) okres 3, od 2008.10 do 2012.08, 47 miesięcy, 12 notowanych spółek PE;

4) okres 4, od 2012.09 do 2016.08, 48 miesięcy, 26 notowanych spółek PE.

Do obliczeń nie weszły więc 3 ,najmłodsze” stażem notowań spółki PE oraz początkowe notowania niektórych pozostałych spółek.

Zarówno poszczególne stopy zwrotu, jak i ich średnie oraz odchylenia standardowe wyznaczono jako stopy miesięczne (nie dokonywano ich annualizacji) i podawane są one w jednostce procentowej.

Za stopę zwrotu wolną od ryzyka przyjęto rentowności 10-letnich obligacji skarbowych (dane pochodzą z [OECD]); wykorzystano dane w układzie miesięcznym, a ponieważ rentowności podawane są jako stopy roczne, dla porównywalności przyjęto dla każdego miesiąca 1/12 danej wartości. Z tak przeliczonych danych dla każ- 
dego z 4 okresów wyliczono średnie rentowności miesięczne. Dla okresu 1 średnią wyliczono z nieco krótszego szeregu (44-miesięcznego) ze względu na brak danych z ostatnich 4 miesięcy 2000 r., przy czym ze względu na niską zmienność rentowności obligacji można śmiało przyjąć, że ewentualne zniekształcenie średniej z tego powodu jest statystycznie nieistotne. Średnie te wykorzystano z kolei do wyznaczenia wskaźników Sharpe'a i Treynora.

Do analizy powiązania stóp zwrotu z akcji poszczególnych spółek PE ze stopami zwrotu z benchmarku (WIG) oprócz współczynnika korelacji (Pearsona) wykorzystano również współczynnik determinacji funkcji regresji wyrażonej wzorem:

$$
R_{i}=\alpha_{i}+\beta_{i} R_{M}+e_{i},
$$

gdzie: $R_{i}$ - stopa zwrotu z akcji spółki $i ; R_{M}$ - stopa zwrotu z rynku (benchmarku WIG); $\alpha_{i}$ i $\beta_{i}$-współczynniki funkcji regresji ( $\beta$ jest popularnym wśród inwestorów parametrem odzwierciedlającym ryzyko systematyczne inwestycji w daną akcję); $e_{i}$-składnik losowy równania.

Przy szacowaniu parametrów tego równania metodą najmniejszych kwadratów wyznaczany jest współczynnik determinacji $\left(\mathrm{R}^{2}\right)$, który pokazuje, w jak dużym stopniu oszacowane równanie wyjaśnia rzeczywiste wartości przyjmowane przez zmienną objaśnianą (w tym przypadku: zmienność stopy zwrotu $\mathrm{z}$ akcji spółki $i$ ). Można przyjąć, że im wyższy współczynnik, tym bardziej kształtowanie stopy zwrotu z tej akcji skorelowane jest ze stopami zwrotu z WIG. Współczynnik ten powinien dawać, co do zasady, wnioski zbieżne do tych wyciąganych na podstawie współczynnika korelacji.

Do celów porównawczych oprócz akcji notowanych spółek PE oraz benchmarków zbadano również wyniki portfela akcji określonego jako „portfel PE”, a składającego się ze wszystkich dostępnych w danym miesiącu akcji notowanych spółek PE. Stopa zwrotu $\mathrm{z}$ tego portfela $\mathrm{w}$ danym miesiącu jest wyliczona jako średnia stopa zwrotu ze stóp zwrotu wszystkich spółek PE, które wprowadzono do notowań nie później niż w miesiącu poprzedzającym. Przyjęto proporcjonalne (równe) udziały wszystkich akcji w tym portfelu. Tak określony portfel jest swego rodzaju indeksem (bardzo uproszczonym) mającym odzwierciedlać koniunkturę w segmencie akcji notowanych spółek PE.

\section{Wyniki badania}

Wyznaczone średnie stopy zwrotu i odchylenia standardowe dla poszczególnych okresów zaprezentowano w tab. 2, a graficzną ilustracją tych danych są dwa wykresy (rys. 3 i 4 ).

Badanie wykazało, że średnie stopy zwrotu z inwestycji w akcje notowanych spółek PE są generalnie wyższe od analogicznych stóp zwrotu z indeksu WIG. W trzech z czterech badanych okresów większość spółek dała średnią stopę zwrotu 
Tabela 2. Średnie stopy zwrotu i odchylenia standardowe stóp zwrotu z akcji notowanych w Polsce spółek PE oraz z benchmarków w badanych okresach

\begin{tabular}{|c|c|c|c|c|c|c|c|c|}
\hline \multirow{2}{*}{ Opis } & \multicolumn{4}{|c|}{ Średnie stopy zwrotu } & \multicolumn{4}{|c|}{ Odchylenia standardowe } \\
\hline & okres 1 & okres 2 & okres 3 & okres 4 & okres 1 & okres 2 & okres 3 & okres 4 \\
\hline $06 \mathrm{~N}$ & 0,8 & 0,1 & $-2,2$ & $-0,5$ & 8,5 & 17,5 & 21,2 & 6,7 \\
\hline IMP & 1,5 & 4,4 & $-1,7$ & $-2,1$ & 13,0 & 19,3 & 14,0 & 7,9 \\
\hline CTC & 0,2 & $-1,0$ & 2,2 & $-1,2$ & 30,3 & 17,4 & 21,8 & 34,6 \\
\hline MCI & - & 3,1 & 0,6 & 2,0 & - & 16,8 & 19,3 & 6,8 \\
\hline $\mathrm{CPA}$ & - & 13,8 & $-0,3$ & 2,2 & - & 99,2 & 15,0 & 9,9 \\
\hline BMP & - & - & 0,3 & 0,4 & - & - & 12,8 & 9,2 \\
\hline BLU & - & - & $-1,9$ & 0,5 & - & - & 15,7 & 16,9 \\
\hline IQP & - & - & 1,5 & 0,5 & - & - & 22,0 & 15,7 \\
\hline INV & - & - & 1,4 & $-1,3$ & - & - & 28,7 & 8,4 \\
\hline ERN & - & - & 0,9 & 6,7 & - & - & 40,9 & 19,0 \\
\hline IFC & - & - & 5,5 & $-0,4$ & - & - & 43,7 & 22,6 \\
\hline SKL & - & - & 0,3 & $-1,8$ & - & - & 23,3 & 14,4 \\
\hline $\mathrm{BPC}$ & - & - & - & 9,7 & - & - & - & 59,5 \\
\hline LEO & - & - & - & 10,1 & - & - & - & 52,0 \\
\hline VTI & - & - & - & 7,1 & - & - & - & 17,4 \\
\hline QRK & - & - & - & 2,3 & - & - & - & 36,8 \\
\hline RUN & - & - & - & $-5,1$ & - & - & - & 26,6 \\
\hline TXF & - & - & - & 1,6 & - & - & - & 32,8 \\
\hline $\mathrm{SSO}$ & - & - & - & 3,7 & - & - & - & 38,2 \\
\hline GRM & - & - & - & 5,1 & - & - & - & 60,6 \\
\hline AER & - & - & - & 2,7 & - & - & - & 18,1 \\
\hline VCP & - & - & - & 0,2 & - & - & - & 20,9 \\
\hline PCV & - & - & - & 12,1 & - & - & - & 95,5 \\
\hline $\mathrm{NOV}$ & - & - & - & 0,3 & - & - & - & 35,1 \\
\hline CTF & - & - & - & 4,7 & - & - & - & 38,8 \\
\hline MEI & - & - & - & 0,8 & - & - & - & 29,0 \\
\hline $\mathrm{L} / \mathrm{G} *$ & $2 / 1$ & $3 / 2$ & $6 / 6$ & $17 / 9$ & $0 / 3$ & $0 / 5$ & $0 / 12$ & $0 / 26$ \\
\hline Portfel PE & 1,59 & 3,01 & 0,31 & 2,15 & 12,3 & 19,8 & 10,8 & 7,3 \\
\hline Średnia PE & 0,83 & 4,09 & 0,56 & 2,32 & 17,3 & 34,0 & 23,2 & 28,2 \\
\hline Mediana PE & 0,85 & 3,13 & 0,48 & 1,16 & 13,0 & 17,5 & 21,5 & 21,7 \\
\hline WIG & 0,82 & 1,07 & 0,50 & 0,37 & 7,1 & 6,1 & 7,3 & 3,8 \\
\hline $\mathrm{NCI}$ & - & - & $-0,74$ & $-0,30$ & - & - & 5,7 & 3,4 \\
\hline
\end{tabular}

* L / G - stosunek liczby spółek PE lepszych od WIG do liczby spółek PE gorszych od WIG.

Źródło: opracowanie własne, dane z [Stooq; GPWInfoStrefa]. 


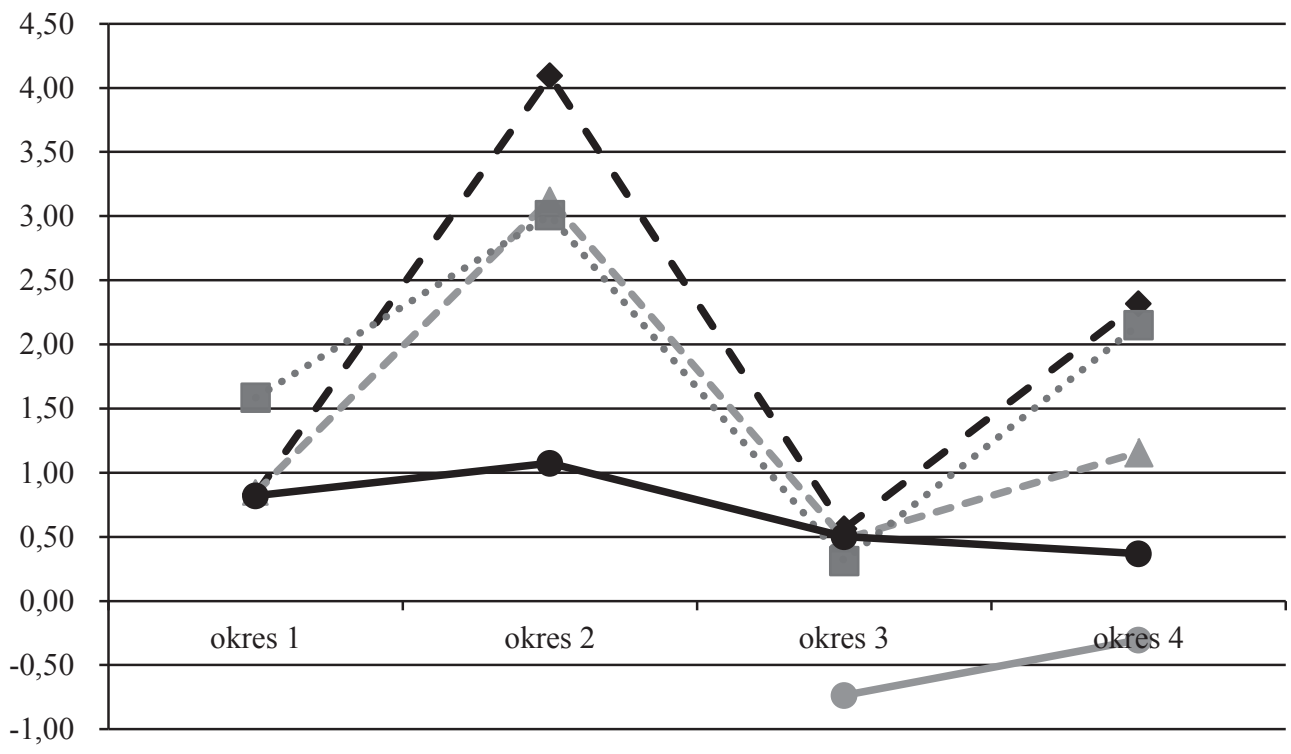

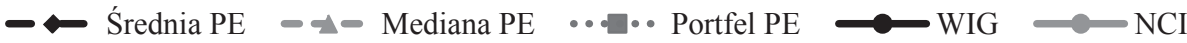

Rys. 3. Średnie stopy zwrotu z akcji notowanych w Polsce spółek PE oraz z benchmarków w badanych okresach

Źródło: opracowanie własne na podstawie danych z tab. 2.

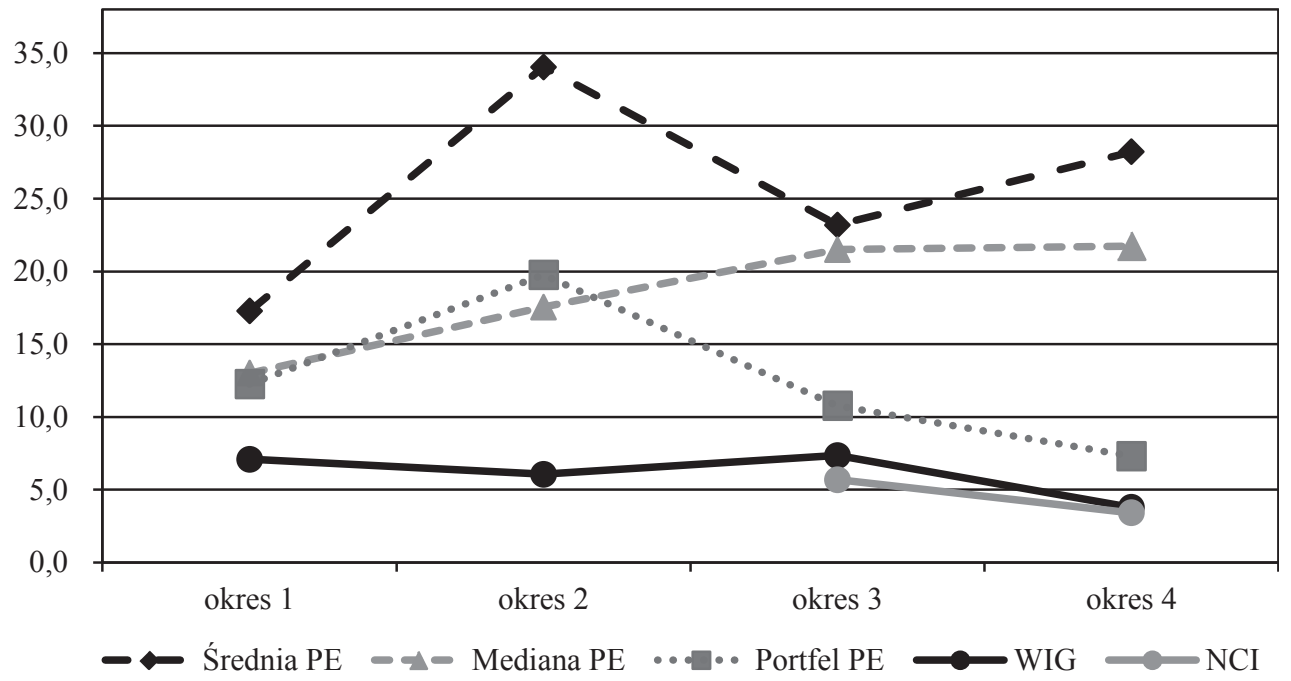

Rys. 4. Odchylenia standardowe stóp zwrotu z akcji notowanych w Polsce spółek PE oraz z benchmarków w badanych okresach

Źródło: opracowanie własne na podstawie danych z tab. 2. 
wyższą od średniej stopy zwrotu z WIG i tylko w 3. okresie liczba spółek lepszych pod tym względem od WIG była równa liczbie spółek gorszych (po 6). Za to w okresie 4. spółek o dochodowości wyższej od WIG było prawie dwa razy więcej niż tych o dochodowości niższej. Podobne wnioski przynosi analiza miar statystycznych badanej zbiorowości - średnia arytmetyczna średnich stóp zwrotu we wszystkich okresach przekraczała stopę wyznaczoną dla WIG, a w okresach 2. i 4. różnice te były znaczne. Mediana również zwykle była wyższa, jedynie w okresie 3. WIG dał zwrot minimalnie wyższy od niej. Zbliżone do miar średnich wyniki wykazał również portfel PE, który tylko w okresie 3. wypadł nieco gorzej niż WIG. Co do indeksu NCI, to w okresach, w których był już publikowany (czyli 3. i 4.), dał on ujemne stopy zwrotu, w oczywisty sposób sytuując się o wiele niżej od dochodowości $\mathrm{z}$ akcji spółek PE. Wnioski te pozwalają stwierdzić, że nie ma podstaw do odrzucenia hipotezy 1 , iż stopy zwrotu $\mathrm{z}$ inwestycji $\mathrm{w}$ akcje spólek private equity notowanych na polskim rynku akcji są wyższe niż stopy zwrotu z całego rynku akcji.

Ocena ryzyka inwestowania w akcje notowanych spółek PE, mierzonego odchyleniem standardowym stóp zwrotu, jest jeszcze bardziej jednoznaczna. Ryzyko to we wszystkich okresach okazało się wyższe od ryzyka charakteryzującego WIG (jak i NCI). Ponadto rys. 4 zwraca uwagę na to, jak pojawienie się nowych spółek wpłynęło na charakterystyki tej zbiorowości: zarówno średnia arytmetyczna wyznaczonych odchyleń standardowych, jak i ich mediana pozostały wysokie, podczas gdy odchylenie standardowe portfela PE uległo znacznemu obniżeniu. Efektu tego nie zaobserwowano na poprzednim wykresie (rys. 3), który pokazywał same średnie stopy zwrotu, a to dlatego, że wyznaczanie stopy zwrotu z portfela PE sprowadza się do uśrednienia stóp zwrotu $\mathrm{z}$ akcji, które go tworzą (niewielka różnica między wyznaczoną tu średnią dla spółek PE a portfelem PE wynika z nieco szerszego zbioru akcji uwzględnianych przy wyliczaniu stopy zwrotu z portfela). Natomiast w przypadku ryzyka średnia dla odchyleń standardowych wszystkich spółek PE jest czymś zupełnie innym niż odchylenie standardowe dla portfela, ponieważ $\mathrm{w}$ jego zakresie zachodzi zjawisko dywersyfikacji (tym silniejsze, im więcej instrumentów i niższe korelacje stóp zwrotu między nimi). Osiągnięta w ten sposób redukcja ryzyka jest dobrze widoczna w okresach 3. i 4., w których indywidualnie wyznaczone ryzyka (więc i ich średnia dla całej zbiorowości) pozostają wysokie, ryzyko portfela zaś znacznie maleje. Niemniej jednak nawet efekt dywersyfikacji nie sprowadził ryzyka charakteryzującego portfel PE poniżej analogicznego parametru wyznaczonego dla WIG (oraz NCI). Ostatecznie więc za pozytywnie zweryfikowaną należy uznać hipotezę 2, według której ryzyko inwestycji w akcje spólek private equity notowanych na polskim rynku akcji jest wyższe niż ryzyko dla całego rynku akcji.

Jak wiadomo, sama wysoka dochodowość (średnia stóp zwrotu) nie oznacza, że dany papier wartościowy jest atrakcyjnym instrumentem inwestycyjnym. Oczekiwana dochodowość powinna bowiem w odpowiednim stopniu rekompensować ryzyko takiej inwestycji. W analizie portfelowej problem ten rozwiązano przez skonstruowanie wskaźników efektywności inwestycyjnej, z których w niniejszej pracy wykorzystano dwa: wskaźnik Sharpe'a i wskaźnik Treynora. Oba polegają na wyznaczeniu stosunku 
premii za ryzyko (nadwyżki średniej stopy zwrotu ponad stopę zwrotu wolną od ryzyka) do samego ryzyka, przy czym w pierwszym ryzyko określone jest odchyleniem standardowym stóp zwrotu, a w drugim - współczynnikiem beta.

Wyniki tej części badania zaprezentowano w tab. 3 oraz na rys. 5 i 6.

Tabela 3. Wskaźniki Sharpe'a i Treynora dla akcji notowanych w Polsce spółek PE oraz benchmarków w badanych okresach

\begin{tabular}{|c|c|c|c|c|c|c|c|c|}
\hline \multirow{2}{*}{ Opis } & \multicolumn{4}{|c|}{ Wskaźniki Sharpe'a } & \multicolumn{4}{|c|}{ Wskaźniki Treynora } \\
\hline & okres 1 & okres 2 & okres 3 & okres 4 & okres 1 & okres 2 & okres 3 & okres 4 \\
\hline $06 \mathrm{~N}$ & 0,02 & $-0,02$ & $-0,13$ & $-0,12$ & $-3,49$ & $-0,25$ & $-2,06$ & $-3,37$ \\
\hline IMP & 0,06 & 0,20 & $-0,16$ & $-0,30$ & $-64,17$ & 2,54 & $-2,47$ & $-3,94$ \\
\hline CTC & $-0,02$ & $-0,08$ & 0,08 & $-0,04$ & $-0,51$ & $-0,76$ & 1,11 & $-0,80$ \\
\hline MCI & - & 0,16 & 0,01 & 0,26 & - & 1,75 & 0,08 & 1,49 \\
\hline $\mathrm{CPA}$ & - & 0,13 & $-0,05$ & 0,19 & - & 4,46 & $-0,57$ & 1,98 \\
\hline BMP & - & - & $-0,01$ & 0,01 & - & - & $-0,21$ & $-1,46$ \\
\hline BLU & - & - & $-0,15$ & 0,01 & - & - & $-5,10$ & $-4,52$ \\
\hline IQP & - & - & 0,04 & 0,01 & - & - & 0,52 & 0,49 \\
\hline INV & - & - & 0,03 & $-0,19$ & - & - & 4,51 & 9,72 \\
\hline ERN & - & - & 0,01 & 0,34 & - & - & 0,23 & 145,31 \\
\hline IFC & - & - & 0,12 & $-0,03$ & - & - & 3,95 & $-2,30$ \\
\hline SKL & - & - & $-0,01$ & $-0,14$ & - & - & $-0,16$ & $-10,20$ \\
\hline $\mathrm{BPC}$ & - & - & - & 0,16 & - & - & - & 14,93 \\
\hline LEO & - & - & - & 0,19 & - & - & - & $-17,25$ \\
\hline VTI & - & - & - & 0,39 & - & - & - & 10,91 \\
\hline QRK & - & - & - & 0,05 & - & - & - & $-3,82$ \\
\hline RUN & - & - & - & $-0,20$ & - & - & - & 10,54 \\
\hline TXF & - & - & - & 0,04 & - & - & - & 1,31 \\
\hline SSO & - & - & - & 0,09 & - & - & - & 1,30 \\
\hline GRM & - & - & - & 0,08 & - & - & - & 2,33 \\
\hline AER & - & - & - & 0,13 & - & - & - & 2,66 \\
\hline $\mathrm{VCP}$ & - & - & - & $-0,00$ & - & - & - & $-2,07$ \\
\hline $\mathrm{PCV}$ & - & - & - & 0,12 & - & - & - & $-4,02$ \\
\hline $\mathrm{NOV}$ & - & - & - & 0,00 & - & - & - & 0,01 \\
\hline CTF & - & - & - & 0,11 & - & - & - & 6,60 \\
\hline MEI & - & - & - & 0,02 & - & - & - & 0,42 \\
\hline $\mathrm{L} / \mathrm{G}^{*}$ & $1 / 2$ & $3 / 2$ & $6 / 6$ & $13 / 13$ & $0 / 3$ & $3 / 2$ & $6 / 6$ & $14 / 12$ \\
\hline Portfel PE & 0,08 & 0,13 & $-0,02$ & 0,26 & 1,55 & 1,55 & $-0,15$ & 4,02 \\
\hline Średnia PE & 0,02 & 0,08 & $-0,02$ & 0,05 & $-22,72$ & 1,55 & $-0,01$ & 6,01 \\
\hline Mediana PE & 0,02 & 0,13 & $-0,00$ & 0,03 & $-3,49$ & 1,75 & $-0,04$ & 0,45 \\
\hline WIG & 0,02 & 0,10 & 0,00 & 0,02 & 0,17 & 0,61 & 0,01 & 0,08 \\
\hline NCI & - & - & $-0,22$ & $-0,17$ & - & - & $-2,23$ & $-2,60$ \\
\hline
\end{tabular}

* L / G - stosunek liczby spółek PE lepszych od WIG do liczby spółek PE gorszych od WIG.

Źródło: opracowanie własne, dane z [Stooq; GPWInfoStrefa; OECD]. 


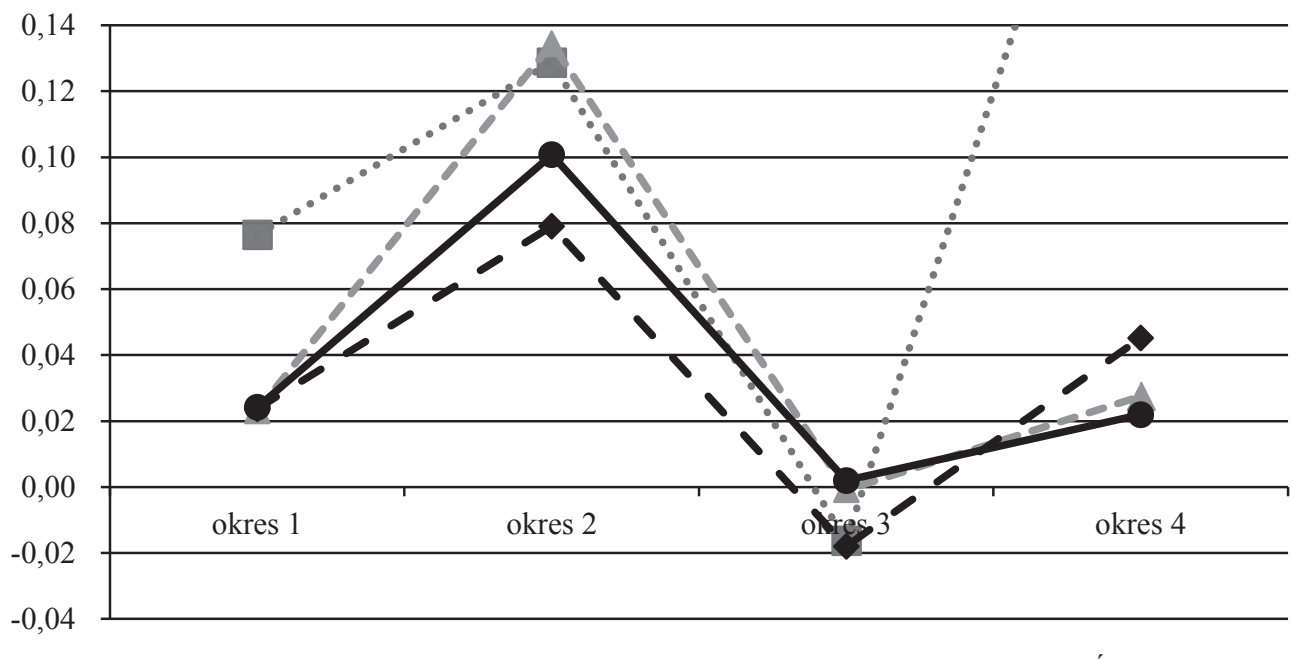

Rys. 5. Wskaźnik Sharpe’a dla akcji notowanych w Polsce spółek PE oraz benchmarku w badanych okresach

Źródło: opracowanie własne na podstawie danych z tab. 3.

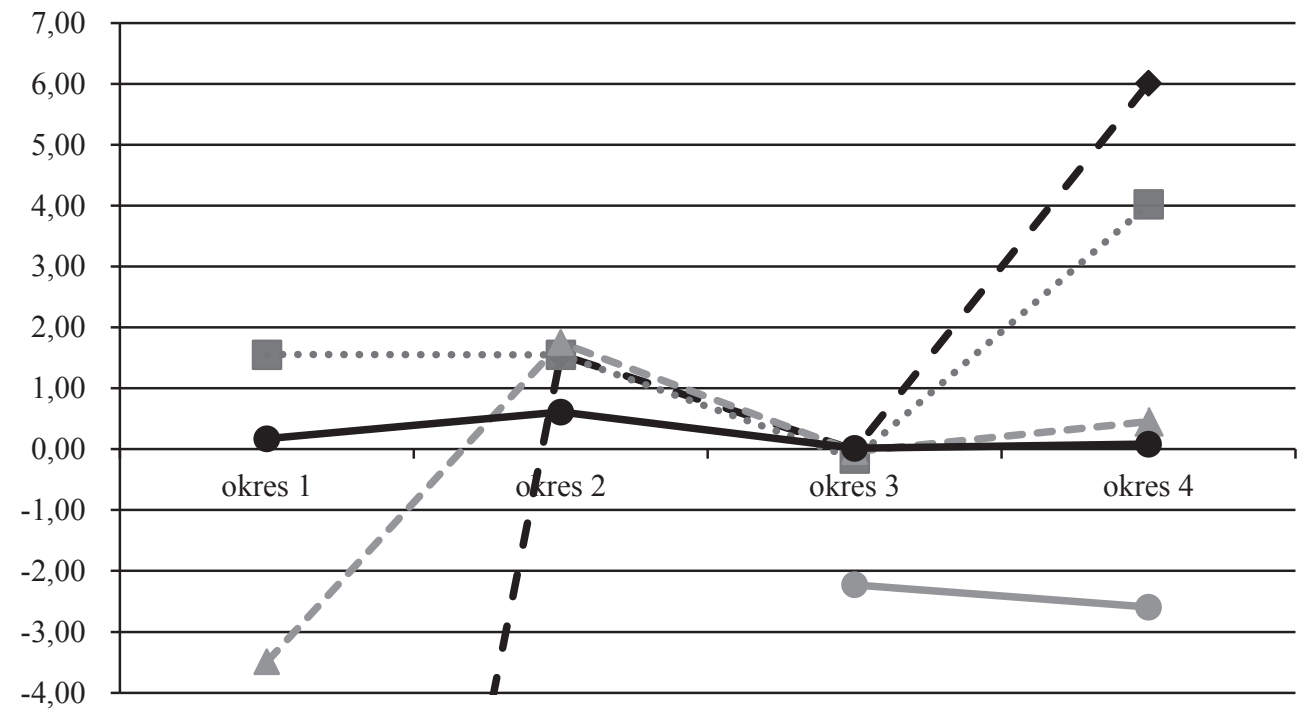

$\multimap$ Średnia PE ...

Rys. 6. Wskaźnik Treynora dla akcji notowanych w Polsce spółek PE oraz benchmarków w badanych okresach

Źródło: opracowanie własne na podstawie danych z tab. 3. 
Zaprezentowane wyniki badań wskazują, że efektywność inwestycji w akcje spółek PE podlega podobnym wahaniom, jak efektywność inwestycji na szerokim rynku akcji, jednakże wyższości tych pierwszych nad drugimi nie można stwierdzić. Liczba spółek o efektywności większej i mniejszej od efektywności dla WIG rozkłada się praktycznie po równo, szczególnie w dwóch ostatnich okresach objętych badaniem. Średnia wartości wskaźnika Sharpe'a dla spółek PE jest równa wartości tego wskaźnika dla WIG w 1. okresie, niższa w dwóch kolejnych okresach i wyższa w ostatnim, natomiast mediana wykazuje wartość bardzo zbliżoną (praktycznie równą) w okresach 1. i 3. oraz nieco wyższą w okresach 2. i 4. Jedynie portfel złożony ze spółek PE w 3 z 4 okresów dość wyraźnie przewyższa efektywnością inwestycyjną portfel rynkowy (tj. benchmark - WIG). Wskaźnik Treynora dla spółek PE wykazuje znacznie większe wahania, a jego wartości są naprzemiennie niższe i wyższe od wskaźnika dla WIG. Podobnie zachowuje się mediana, choć jej wartości charakteryzuje mniejszy rozrzut w poszczególnych okresach. Ponownie tylko portfel PE okazuje się lepszy niż WIG w 3 na 4 badane okresy. Otrzymawszy tak zróżnicowane wyniki, nie można wskazać na jednoznaczną przewagę wskaźników efektywności spółek PE nad wskaźnikiem dla WIG lub odwrotnie. Wobec tego należy odrzucić hipotezę 3 i stwierdzić, że efektywność inwestycji w akcje spółek private equity notowanych na polskim rynku akcji nie jest wyższa niż efektywność dla całego rynku akcji. Należy jednak podkreślić, że nie jest to podstawa do sformułowania hipotezy przeciwnej, tj. że efektywność ta jest niższa - taki wniosek również jest nieuprawniony.

Warto również dygresyjnie zwrócić uwagę, iż rynek NewConnect, który miał być odpowiednikiem dynamicznych zagranicznych rynków spółek technologicznych (jak amerykański Nasdaq), w niniejszym badaniu wykazał się bardzo niską efektywnością inwestycyjną ${ }^{2}$, odstając pod tym względem zarówno od głównego rynku akcji (reprezentowanego przez WIG), jak i od akcji spółek PE, rozumianych tu jako pewna zbiorowość.

Dla zweryfikowania hipotezy 4 , tj. sprawdzenia, na ile akcje notowanych spółek PE pozwalają redukować ryzyko portfeli złożonych z akcji dostępnych na polskim rynku, konieczne jest odwołanie się do koncepcji dywersyfikacji ryzyka funkcjonującej w ramach analizy portfelowej. Opiera się ona na założeniu, że im słabiej skorelowane są ze sobą stopy zwrotu z danych instrumentów finansowych, tym większej redukcji ulega odchylenie standardowe uśrednionej stopy zwrotu z portfela stworzonego z tych instrumentów. Oznacza to, że aby efektywnie dywersyfikować (i w efekcie redukować) ryzyko, należy do portfela dobierać walory o słabo skorelowanych stopach zwrotu. Szczególnym, acz rzadkim przypadkiem jest korelacja ujemna, która tym bardziej pozwala wykorzystać efekt dywersyfikacji i w takiej sytuacji im silniejsza jest korelacja, tym większa redukcja ryzyka. W związku z tym niniejsza część badania sprowadza się do wyznaczenia i oceny wskaźników korela-

\footnotetext{
${ }^{2}$ Ze względu na bardzo niskie wartości indeks NCI został wykluczony z prezentacji na rys. 5.
} 
Tabela 4. Współczynniki korelacji Pearsona i współczynniki determinacji funkcji regresji $\left(\mathrm{R}^{2}\right)$ dla akcji notowanych w Polsce spółek PE oraz benchmarków w badanych okresach

\begin{tabular}{|c|c|c|c|c|c|c|c|c|}
\hline \multirow{2}{*}{ Opis } & \multicolumn{4}{|c|}{ Współczynniki korelacji Pearsona } & \multicolumn{4}{|c|}{ Współczynniki determinacji ( $\left.\mathrm{R}^{2}\right)$} \\
\hline & okres 1 & okres 2 & okres 3 & okres 4 & okres 1 & okres 2 & okres 3 & okres 4 \\
\hline $06 \mathrm{~N}$ & $-0,05$ & 0,43 & 0,45 & 0,14 & 0,00 & 0,19 & 0,21 & 0,02 \\
\hline IMP & $-0,01$ & 0,48 & 0,47 & 0,29 & 0,00 & 0,23 & 0,22 & 0,08 \\
\hline CTC & 0,22 & 0,65 & 0,53 & 0,21 & 0,05 & 0,43 & 0,28 & 0,04 \\
\hline MCI & - & 0,55 & 0,70 & 0,65 & - & 0,30 & 0,50 & 0,42 \\
\hline CPA & - & 0,18 & 0,64 & 0,36 & - & 0,03 & 0,41 & 0,13 \\
\hline BMP & - & - & 0,44 & $-0,03$ & - & - & 0,19 & 0,00 \\
\hline BLU & - & - & 0,22 & $-0,01$ & - & - & 0,05 & 0,00 \\
\hline IQP & - & - & 0,64 & 0,11 & - & - & 0,41 & 0,01 \\
\hline INV & - & - & 0,05 & $-0,07$ & - & - & 0,00 & 0,01 \\
\hline ERN & - & - & 0,34 & 0,01 & - & - & 0,11 & 0,00 \\
\hline IFC & - & - & 0,21 & 0,05 & - & - & 0,05 & 0,00 \\
\hline SKL & - & - & 0,43 & 0,05 & - & - & 0,18 & 0,00 \\
\hline BPC & - & - & - & 0,04 & - & - & - & 0,00 \\
\hline LEO & - & - & - & $-0,04$ & - & - & - & 0,00 \\
\hline VTI & - & - & - & 0,14 & - & - & - & 0,02 \\
\hline QRK & - & - & - & $-0,05$ & - & - & - & 0,00 \\
\hline RUN & - & - & - & $-0,07$ & - & - & - & 0,01 \\
\hline TXF & - & - & - & 0,11 & - & - & - & 0,01 \\
\hline $\mathrm{SSO}$ & - & - & - & 0,26 & - & - & - & 0,07 \\
\hline GRM & - & - & - & 0,13 & - & - & - & 0,02 \\
\hline AER & - & - & - & 0,19 & - & - & - & 0,04 \\
\hline VCP & - & - & - & 0,01 & - & - & - & 0,00 \\
\hline PCV & - & - & - & $-0,12$ & - & - & - & 0,01 \\
\hline $\mathrm{NOV}$ & - & - & - & 0,28 & - & - & - & 0,08 \\
\hline $\mathrm{CTF}$ & - & - & - & 0,07 & - & - & - & 0,00 \\
\hline MEI & - & - & - & 0,15 & - & - & - & 0,02 \\
\hline Portfel PE & 0,3 & 0,5 & 0,8 & 0,2 & 0,1 & 0,3 & 0,6 & 0,1 \\
\hline Średnia PE & 0,1 & 0,5 & 0,4 & 0,1 & 0,0 & 0,2 & 0,2 & 0,0 \\
\hline Mediana PE & $-0,0$ & 0,5 & 0,4 & 0,1 & 0,0 & 0,2 & 0,2 & 0,0 \\
\hline WIG & 1,0 & 1,0 & 1,0 & 1,0 & 1,0 & 1,0 & 1,0 & 1,0 \\
\hline NCI & - & - & 0,7 & 0,3 & - & - & 0,5 & 0,1 \\
\hline
\end{tabular}

Źródło: opracowanie własne, dane z [Stooq; GPWInfoStrefa]. 
cji pomiędzy stopami zwrotu z akcji spółek PE a stopami zwrotu z WIG. Alternatywnym podejściem jest wykorzystanie koncepcji współczynnika beta akcji. Jest to współczynnik kierunkowy funkcji regresji obrazującej zależność zmienności stóp zwrotu z danej akcji od stóp zwrotu z całego rynku. Wartość współczynnika beta pokazuje siłę reakcji stóp zwrotu z akcji na zmiany stóp zwrotu z rynku, a współczynnik determinacji $\left(\mathrm{R}^{2}\right)$ wyznaczony dla tak oszacowanego równania pozwala ocenić, na ile zmienna objaśniająca (czyli zmiany sytuacji na rynku) pozwala objaśnić zmienną objaśniającą (czyli stopy zwrotu z danej akcji). Wysoki współczynnik determinacji (bliski 100\%) oznacza, że stopień objaśnienia jest znaczny, a to z kolei - że stopy zwrotu z danej akcji zachowują się bardzo podobnie do stóp zwrotu $\mathrm{z}$ rynku, nie są więc dobrym instrumentem do dywersyfikowania ryzyka w portfelu. $\mathrm{Z}$ tego punktu widzenia należy poszukiwać akcji o współczynniku determinacji jak najniższym, bo umożliwiają one uzyskanie silniejszego efektu dywersyfikacji.

Wnioski z przeprowadzonego badania są dość jednoznaczne. Współczynnik korelacji Pearsona przyjmuje wartości z przedziału od -1 do 1, przy czym za korelację silną uważa się zwykle wartość bezwzględną wskaźnika wyższą niż 0,7 , natomiast wartość bliską zeru uznaje się za brak korelacji. Wartość 0,7 wystąpiła w przypadku akcji tylko jednej spółki (MCI) i tylko w jednym okresie, we wszystkich pozostałych przypadkach wartości te są niższe, w przeważającej większości mieszczą się one w zakresie od $-0,12$ do 0,29 , co można śmiało uznać za brak korelacji. Podobnie rzecz się ma ze współczynnikiem determinacji - w wielu przypadkach przyjął on wartości praktycznie zerowe, wartości większe od 0,1 stanowiły mniejszość, a najwyższa osiągnięta wartość to 0,5 (dla porównania, przy modelowaniu ekonometrycznym oczekuje się dopasowań wyrażonych wskaźnikiem wyższym niż 0,9). Tak niski związek zmienności stóp zwrotu z akcji spółek PE ze stopami zwrotu z całego rynku oznacza, że akcje te, włączone do szerszego portfela inwestycyjnego, powinny w istotny sposób zdywersyfikować jego strukturę i zredukować ryzyko. Wobec tego należy uznać za zweryfikowaną pozytywnie hipotezę 4, według której akcje notowanych w Polsce spółek private equity pozwalają znacznie redukować ryzyko portfeli inwestycyjnych zlożonych $\mathrm{z}$ akcji dostępnych na polskim rynku.

Należy przy tym nadmienić, że wynikająca z takiej dywersyfikacji redukcja ryzyka nie oznacza automatycznie zwiększenia efektywności inwestycyjnej takiego portfela. Po pierwsze, w niektórych przypadkach do osiągnięcia redukcji ryzyka konieczne byłoby zastosowanie wobec akcji spółek PE tzw. krótkiej sprzedaży, która jednak w ich wypadku jest nieosiągalna (polski rynek akcji nie jest pod tym względem tak rozwinięty, jak rynki zagraniczne). Po drugie, w przypadku spółek PE o średniej stopie zwrotu niższej od stopy zwrotu z WIG redukcja ryzyka osiągnięta przez włączenie tych akcji do portfela może być niewystarczająca do zrekompensowania ubytku dochodowości, czyli premii za ryzyko, i w efekcie efektywność rozszerzonego portfela (mierzona wskaźnikiem Sharpe'a lub Treynora) może się okazać niższa niż przed rozszerzeniem. Niemniej jednak sam fakt możliwości znacznego obniżenia ryzyka za pomocą akcji spółek PE czyni z nich potencjalnie atrakcyjny instrument inwestycyjny. 


\section{Zakończenie}

Rynek private equity w Polsce wciąż można uznać za młody, ale cechuje go relatywnie wysoka dynamika rozwoju. W miarę zwiększania się jego rozmiarów wzrasta też zakres możliwości jego powiązań z innymi sferami gospodarczego uniwersum, czego przejawem jest korzystanie z notowań publicznych jako źródła dokapitalizowania. $\mathrm{Z}$ kolei dla inwestorów giełdowych wprowadzenie spółki private equity na rynek publiczny oznacza umożliwienie im uczestnictwa w jej zyskach, co w przypadku typowych (nienotowanych) spółek PE ograniczone jest do wąskiego grona kapitałodawców, którzy do udziału w tej działalności zostają zaproszeni. Z tego punktu widzenia ciekawym zagadnieniem jest atrakcyjność inwestycji w akcje notowanych spółek PE. Przedstawione w artykule badanie, obejmujące 29 firm PE notowanych na GPW lub NewConnect, pokazuje, że ich akcje dają generalnie wyższe stopy zwrotu niż średnie stopy dostępne z szerokiego rynku (reprezentowanego przez indeks WIG), ale przy wyższym ryzyku (mierzonym odchyleniem standardowym). Wyższe ryzyko i wyższa dochodowość tych akcji kompensują się nawzajem, w wyniku czego efektywność inwestycji w nie (mierzona wskaźnikami Sharpe'a i Treynora) okazuje się porównywalna $z$ efektywnością wyznaczoną dla indeksu WIG. Niemniej jednak wykazano również, że stopy zwrotu z akcji notowanych spółek private equity cechuje niski związek ze stopami zwrotu z WIG, dzięki czemu są one instrumentami umożliwiającymi znaczną redukcję ryzyka portfeli inwestycyjnych złożonych z akcji dostępnych na polskim rynku.

\section{Literatura}

Aigner P., Beyschlag G., Friederich T., Kalepky M., Zagst R., 2012, Modelling and managing portfolios including listed private equity, Computers and Operations Research, vol. 39 (4), s. 753-764.

Bankier, serwis internetowy, www.bankier.pl (dostęp 18.08.2016).

Bergmann B., Christophers H., Huss M., Zimmermann H., 2010, Listed Private Equity, [w:] Cumming D. (red.), Private Equity: Fund Types, Risks and Returns, and Regulation, John Wiley \& Sons, Inc., s. 53-70.

Bilo S., Christophers H., Degosciu M., Zimmermann H., 2005, Risk, returns, and biases of listed private equity portfolios, Working Paper, University of Basel.

Cumming D., Fleming G., Johan S.A., 2011, Institutional investment in listed private equity, European Financial Management, vol. 17(3), s. 594-618.

Degosciu M., 2012, Listed vs. Unlisted Private Equity (First Version), http://ssrn.com/abstract=2081997 (dostęp 6.09.2016).

GPW, podstawowe statystyki GPW, https://www.gpw.pl/analizy_i_statystyki_pelna_wersja (dostęp 13.09.2016).

GPWInfoStrefa, serwis informacyjny GPW, www.gpwinfostrefa.pl (dostęp 12.08.2016).

Huss M., 2005, Performance characteristics of private equity. An empirical comparison of listed and unlisted private equity vehicles, Working Paper, University of Basel.

Invesco PowerShares, 2016, PowerShares Global Listed Private Equity Portfolio, www.invesco.com (dostęp 5.09.2016). 
Invest Europe, 2016, European private equity activity data 2007-2015, Invest Europe Research, www. investeurope.eu (dostęp 13.09.2016).

Jajuga K., Jajuga T., 2001, Inwestycje. Instrumenty finansowe. Ryzyko finansowe. Inżynieria finansowa, Wydawnictwo Naukowe PWN, Warszawa.

LPEQ, 2014, 8 Steps for Analysing Listed Private Equity Companies, www.lpeq.com (dostęp 31.08.2016).

LPX Group, http://www.lpx-group.com/listed-private-equity.html (dostęp 31.08.2016).

McGraw Hill Financial, 2016, S\&P Listed Private Equity Index Methodology, www.us.spindices.com (dostęp 05.09.2016).

Money.pl, serwis internetowy, www.money.pl (dostęp 18.08.2016).

NewConnect, serwis internetowy GPW, www.newconnect.pl (dostęp 12.08.2016).

OECD Statistics, baza danych, http://stats.oecd.org (dostęp 24.08.2016).

PSIK (Polskie Stowarzyszenie Inwestorów Kapitałowych), lista członków-funduszy, http://www.psik. org.pl/fundusze.html (dostęp 13.09.2016).

Sharma M., Aggarwal R., 2012, S\&P Listed Private Equity Index: Performance analysis and maximizing the coefficient of determination, The Journal of Private Equity, vol. 15, no. 3, s. 96-101.

Small K., Duncan D., Small E., 2013, The PowerShares Global Listed Private Equity Portfolio: Risk and performance analysis, The Journal of Private Equity, vol. 16, no. 2, s. 99-109.

Sosnowski T., 2014, Dezinwestycje funduszy private equity metoda IPO, Wydawnictwo Uniwersytetu Łódzkiego, Łódź.

Stooq, serwis internetowy, www.stooq.pl (dostęp 16.08.2016).

Tarczyński W., 1997, Rynki kapitałowe. Metody ilościowe, vol. II, Agencja Wydawnicza Placet, Warszawa.

Zasępa P., 2010, Venture capital - sposoby dezinwestycji, CeDeWu Sp. z o.o., Warszawa.

Zimny A., 2009, Trendy rynku PE/VC a trendy rynków giełdowych, [w:] Filipiak B., Mikołajczyk B. (red.), Rynki finansowe w rozwoju podmiotów gospodarczych, Difin, Warszawa.

Zimny A., 2013a, Decyzje na rynkach Venture Capital/Private Equity, Wydawnictwo Uniwersytetu Łódzkiego, Łódź.

Zimny A., 2013b, Koniunktura giełdowa a stopy zwrotu z inwestycji Private Equity, [w:] Zarzecki D. (red.), Zeszyty Naukowe Uniwersytetu Szczecińskiego nr 760, Finanse, Rynki Finansowe, Ubezpieczenia, nr 59, Wydawnictwo Naukowe Uniwersytetu Szczecińskiego, Szczecin. 